\title{
Influence of oceanographic features on spatial and interannual variability of phytoplankton in the Bransfield Strait, Antarctica
}

\author{
Rafael Gonçalves-Araujo *,1, Márcio Silva de Souza ${ }^{1}$, Virginia Maria Tavano ${ }^{1}$, Carlos Alberto Eiras Garcia ${ }^{1}$ \\ Instituto de Oceanografia, Universidade Federal do Rio Grande, Av. Itália, Km 8, Rio Grande, RS 96203-900, Brazi
}

\section{A R T I C L E I N F O}

\section{Article history:}

Received 29 April 2014

Received in revised form 28 August 2014

Accepted 15 September 2014

Available online 22 September 2014

\section{Keywords:}

Phytoplankton

Chlorophyll- $a$

Water column structure

Satellite remote sensing

Dissolved macronutrients

Antarctic Peninsula

\begin{abstract}
A B S T R A C T
Spatial variability and interannual variability of phytoplankton biomass, estimated as chlorophyll- $a$ (Chl- $a$ ) concentration and taxonomic groups, were analyzed in relation to environmental conditions in the Bransfield Strait (BS). This study is based upon both in situ (2003, 2004, 2005, 2008, 2009 and 2010) and satellite (2002-2010) data, during the austral summer. A thermohaline front was predominately observed between the colder and saltier waters under the influence of transitional water with Weddell Sea influence (TWW) in the southeastern BS, and the fresher and warmer waters associated with the presence of transitional water with Bellingshausen Sea influence (TBW) in the northwestern BS. Canonical correspondence analysis showed that the dominance of microplanktonic diatoms was associated with higher Chl-a within shallow upper mixed layers, with relatively strong pycnocline in the TBW, particularly close to the South Shetland Islands (SSI). Conversely, the TWW was primarily characterized by lower Chl- $a$ within deeper mixed layers or a well-mixed water column and dominated by nanoplanktonic flagellates (including haptophytes and cryptophytes). Spatial variability based on both in situ and satellite data suggests that the Bransfield Strait acts as a typical Seasonal Ice Zone (SIZ) and the phytoplankton community there is governed by a combination of processes acting synergistically: the sea ice retreat, allowing for a penetration of light into the water column, and a relatively shallow upper mixed layer with strong pycnocline, primarily in the TBW, retaining organisms near the surface when light conditions are adequate. Interannual variability in Chl- $a$ and species composition indicate an alternation between diatomdominated and flagellate-dominated assemblages. These shifts are potentially related to the different stages of phytoplankton succession, as a result of varying water column physical features, principally influenced by the dynamic occupation of the TBW and TWW, that appear to modulate phytoplankton dynamics within the BS.
\end{abstract}

(C) 2014 Elsevier B.V. All rights reserved.

\section{Introduction}

The Southern Ocean is recognized as a pivotal component in the modulation of the global climate and in seawater ventilation through the thermohaline circulation (Sarmiento et al., 2004). In this polar region, phytoplankton standing stock and production can be associated with distinct biogeochemical provinces, where physical features exert a significant influence: the Polar Front zone (PFZ), the permanently open ocean zone (POOZ), the marginal ice zones (MIZ) and the coastal and continental shelf zones (CCS) (Arrigo et al., 1998; Tréguer and Jacques, 1992). In general, the continental shelves and marginal ice zones around Antarctica demonstrate a much higher phytoplankton biomass and productivity in comparison to deep pelagic areas (Arrigo et al., 1998).

\footnotetext{
* Corresponding author at: Alfred Wegener Institute for Polar and Marine Research, Climate Sciences, Bussestraße 24, F-402, D-27570 Bremerhaven, Germany. Tel.: + 494714831 1785; fax: + 4947148311149 .

E-mail addresses: rafael.goncalves.araujo@awi.de (R. Gonçalves-Araujo), souzamsd@gmail.com (M.S. de Souza),docvmtg@furg.br (V.M. Tavano), dfsgar@furg.br (C.A.E. Garcia).

${ }^{1}$ Tel./fax: + 555332336510 .
}

The tip of the Antarctic Peninsula (AP) has long been a concern within the scientific community as it is one of the most susceptible regions in the world to global climate change (Steig et al., 2009; Turner et al., 2005). Environmental shifts within the AP have resulted in changes of biomass and composition within primary producers, particularly phytoplankton (Ducklow et al., 2007; Garibotti et al., 2005; Montes-Hugo et al., 2009; Schloss et al., 2012). Located to the northwest of the tip of the AP, the Bransfield Strait (BS) is a semi-enclosed sea, limited to the north by the South Shetland Islands (SSI) and to the south by the AP itself. The BS is also connected to the Weddell (east) and Bellingshausen (west) Seas, resulting in a complex circulatory system of surface waters within the Strait, with the Southern BS Current (SBSC) carrying waters advected from the Weddell Sea and the Gerlache Strait Current (GSC) carrying waters from the southwest (Jiang et al., 2013). As a result, the subsequent transitional waters can be detected within the surface layer: transitional water with Weddell influence (TWW) and transitional water with Bellingshausen influence (TBW), with each showing particular thermohaline structures (Fig. 1) (Amos, 2001; López et al., 1999; Sangrà et al., 2011, 2014; Zhou et al., 2006). The dynamic interaction between SBSC and GSC produces mesoscale processes, such as anticyclonic eddies, which become separated from those currents by 


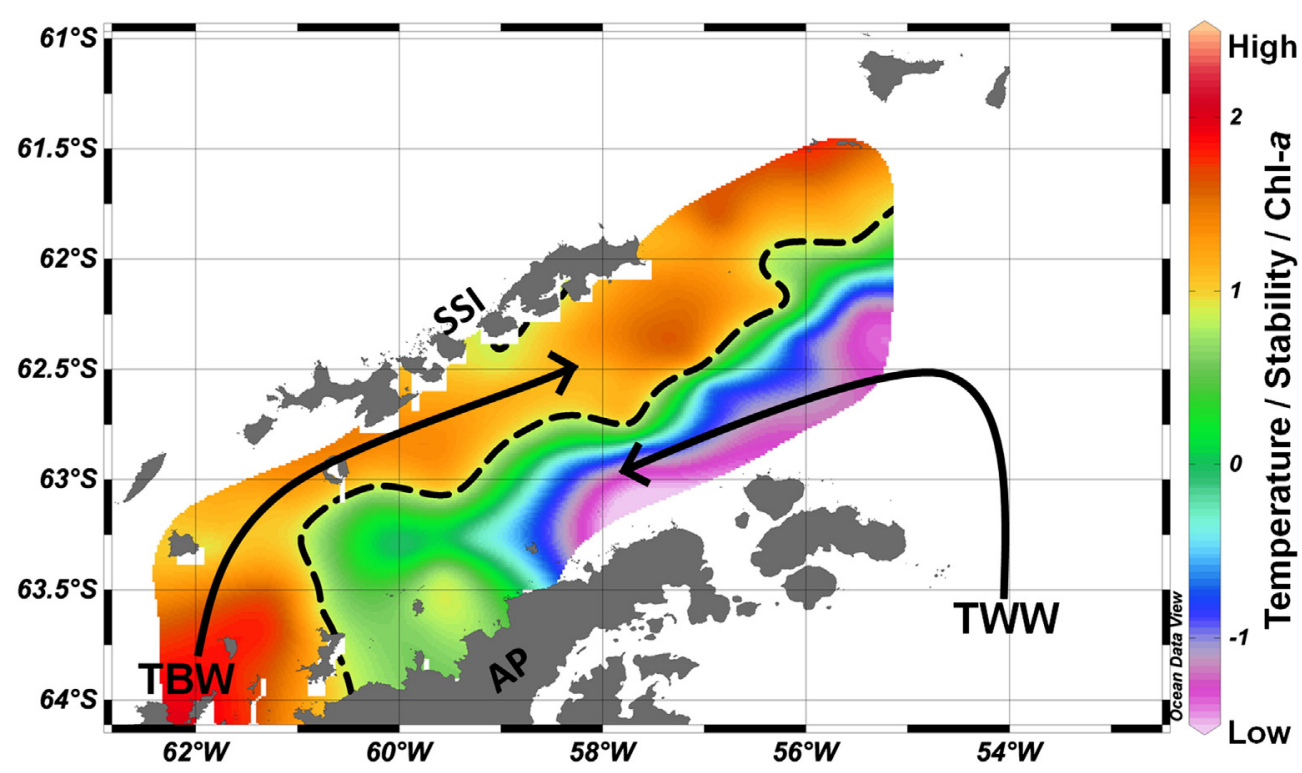

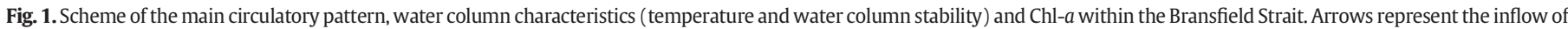

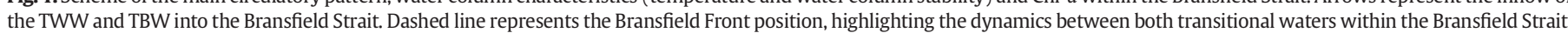

the establishment of two oceanographic fronts: the Bransfield Front (BF) and the Peninsula Front (PF) (Sangrà et al., 2011, 2014). The distribution of those waters, fronts, anticyclonic eddies and their respective thermohaline structures cause variations in the standing stock and composition of the phytoplankton community across the BS (García-Muñoz et al., 2013; Mura et al., 1995; Sangrà et al., 2014).

An eighteen-year research program conducted along the BS showed that the highest chlorophyll- $a$ (Chl- $a$ ) was located close to the SSI and that upper mixed layer depth (UMLD) was negatively related with Chl- $a$ (Hewes et al., 2009). In an eastern sector of the BS, the highest Chl- $a$ was found at or near the surface decreasing toward the deeper layers at well stratified sites, with euphotic layers varying from 40 to $50 \mathrm{~m}$. By contrast, weakly stratified sites, typically under Weddell Sea influence, were associated with low Chl- $a$ and deeper euphotic zones (Holm-Hansen et al., 1997).

During the austral summers of 1995 and 1996, the phytoplankton community within the BS was predominately dominated by either the cryptophyte Cryptomonas sp. (1995) or by the colonial haptophyte Phaeocystis cf. antarctica and small flagellates (1996), with a considerable contribution of diatoms in both years (Rodriguez et al., 2002). In general, phytoplankton blooms around the AP are typically associated with the development of a shallow mixed layer (retaining phytoplankton within adequate light levels) and with iron availability (e.g., Prézelin et al., 2000), and are reported to be typically dominated by diatoms and/or haptophytes (primarily P. antarctica). Nevertheless, several studies have highlighted the increasing importance of cryptophytes in the AP as they prevail over diatoms, particularly within ice melting regions (Moline and Prézelin, 1996; Moline et al., 2004). Several other studies have related the seasonal succession of phytoplankton along the west of the AP (wAP) to the timing of the sea ice retreat, particularly from the south of Gerlache Strait to Marguerite Bay (Garibotti et al., 2005; Prézelin et al., 2000), with some evidence found within the BS (Mendes et al., 2013; Varela et al., 2002). Firstly, diatom blooms attain higher biomass when the sea ice retreat is under way and, with a continued stratification, cryptophytes can numerically replace these diatoms (Ducklow et al., 2007). Finally, a phytoplankton community co-dominated primarily by very small diatoms and other unidentified flagellates are associated with low Chl- $a$ (Garibotti et al., 2005; Moline and Prézelin, 1996). There are numerous sources in the literature on phytoplankton dynamics in some wAP systems, principally near Marguerite Bay (Prézelin et al., 2004 and references therein).
However, the processes that modulate phytoplankton distribution in open sea regions and their relationship to the dynamics of the water masses, particularly within the BS, are poorly understood. As stated in Garibotti et al. (2005), it is not known if the phytoplankton composition changes from year-to-year in some regions within the wAP, and what kind of environmental variability is related to possible phytoplankton composition changes.

In the present study, microscopic data from four summer cruises to the BS (2003, 2004, 2008 and 2009) were analyzed in order to assess the variability in phytoplankton composition over spatial and interannual scales. These samplings can be considered as representative of the range of standing stock and community composition observed during the early and late 2000s in the region. In addition, satellite data, temperature and Chl- $a$ derived from 2003-2010 were used to characterize several differences in the extent of sea ice and Chl-a during summer time. Our specific goals were: (1) to comparatively analyze the composition and biomass distribution of the phytoplankton groups during the four studied summers with available microscopic data; (2) to determine whether the phytoplankton community structure is stable or variable from year-to-year; and (3) to evaluate the ecological mechanisms regulating the spatial and interannual phytoplankton variability.

\section{Material and methods}

\subsection{Sampling}

Sampling and data collection procedures were conducted across the Bransfield Strait during the GOAL (High Latitude Oceanography Group) and SOS-CLIMATE (Southern Ocean Studies for Understanding Global Climate Issues) cruises during the late austral summers of 2003, 2004, 2005, 2008, 2009 and 2010 (Table 1), on board the Brazilian Navy R/V "Ary Rongel”, as part of the Brazilian Antarctic Program and the International Polar Year (IPY 2007-2008). Vertical profiles of temperature and salinity were taken with a SeaBird ${ }^{\circ} 911+$ CTD attached to a Carrousel system bearing 5-L Niskin bottles for water sampling. Water was collected from the surface and several depths for further laboratory analysis of phytoplankton biomass and composition (the later only for the summers of 2003, 2004, 2008 and 2009) and dissolved macronutrients. 


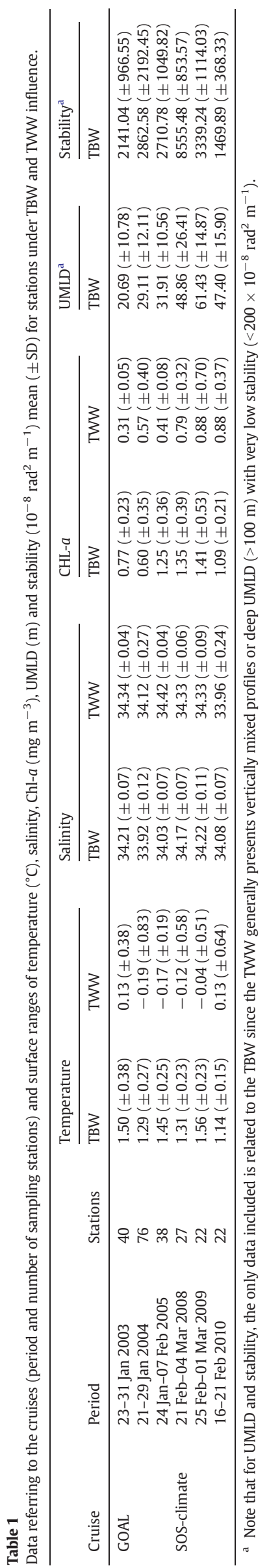

\subsection{Physical parameters}

Potential density was calculated from temperature and salinity data obtained from CTD casts. UMLD was determined through an analysis of vertical density profiles $(\partial \rho / \partial z)$. The depth where variations in density were equal to or greater than 0.02 over $5 \mathrm{~m}$ depth interval was considered the UMLD ( $\mathrm{m}$ ) (adapted from Mitchell and Holm-Hansen, $1991)$. The water column stability parameter $(E)$ was calculated based on vertical density variations, as a function of the buoyancy or Brunt-Väisälä frequency $\left(N^{2}\right)$, which is defined by: $N^{2}=\frac{g}{\rho} \frac{\partial \rho}{\partial z}$ $\left(\operatorname{rad}^{2} \mathrm{~s}^{-2}\right)$ leading to $E=\frac{N^{2}}{g}\left(10^{-8} \operatorname{rad}^{2} \mathrm{~m}^{-1}\right)$, where $g$ is gravity and $\rho$ is the potential density of a water parcel. In this study, it was considered that maximum stability directly below the UMLD should represent the strength of the pycnocline (Castro et al., 2002).

\subsection{Phytoplankton analysis}

Discrete water samples $(0.5-1 \mathrm{~L})$ were filtered onto $25-\mathrm{mm}$ glass fiber filters (Whatman GF/F) for post-cruise determinations of total Chl- $a$ by either a fluorometric or spectrofluorometric method. In addition, discrete water samples $(0.5-1 \mathrm{~L})$ were size-fractionated by sequential filtration through Nuclepore $20-\mu \mathrm{m}$ polycarbonate membranes and Whatman GF/F filters under a vacuum pressure lower than $200 \mathrm{mmHg}$. These size fractions of Chl- $a$ were considered as follows: microplankton for the material retained on the $20-\mu \mathrm{m}$ filter, and nanoplankton + picoplankton (hereafter referred to as "nanoplankton") for the fraction that passed through 20- $\mu$ m however was retained on the Whatman GF/F filter $(0.7 \mu \mathrm{m})$. After filtration, all filters were kept frozen in liquid nitrogen until further analysis. In the laboratory, the pigment was extracted in $90 \%$ acetone and analyzed by one of two techniques. For the 2003 and 2004 cruises, pigment content was determined in a Perkin Elmer LS-60B spectrofluorometer (Neveux and Lantoine, 1993). Emission fluorescence spectra were recorded between 620 and $710 \mathrm{~nm}$, at $0.5 \mathrm{~nm}$ intervals. For the 2005, 2008, 2009 and 2010 cruises, Chl- $a$ was determined using a Turner Designs TD-700 fluorometer, following the non-acidification method of Welschmeyer (1994). In addition, 44 samples were analyzed using both methods in 2004 in order to verify the concurrence between the approaches. Chl- $a$ values using both methods were well correlated ( $r=0.67$, slope $=1.10$ ). Vertical profiles of discrete Chl- $a$ measurements were performed on all six cruises. However, the maximum sampling depth varied between cruises, depending upon logistical issues. In order to compare the data collected from each of the cruises, 50-m integrated Chl- $a\left(\mathrm{mg} \mathrm{m}^{-2}\right)$ was determined.

Phytoplankton counting and identification data were obtained for the 2003, 2004, 2008 and 2009 cruises. Discrete samples ( $200 \mathrm{~mL}$ ) were collected from the sea surface and preserved in either a formaldehyde solution (4\% final concentration) (2003 and 2004 cruises) or in a $2 \%$ alkaline Lugol's iodine solution (2008 and 2009 cruises) for later microscope examination. The alkaline version of this fixative prevents calcite dissolution of coccolithophorid plates or other calcifying structures in microorganisms (D. Iglesias-Rodriguez, pers. comm.). In the laboratory, 50 to $100 \mathrm{~mL}$ sub-samples were analyzed using an inverted microscope, at 200× and 400× magnifications (Utermöhl, 1958). Despite the distinct effects that different fixatives may have on different taxonomic groups (Menden-Deuer et al., 2001), microscopic counting was carefully performed directly after the cruises, in order to minimize variability due to different fixation chemicals on the samples. Phytoplankton composition was determined according to specific literature (Balech, 1988; Dodge, 1982; Hasle and Syvertsen, 1996). Due to either a low concentration of some phytoplankton species or difficulties in distinguishing between species in the light microscope, individual species/genera were grouped as follows: diatoms, dinoflagellates, cryptophytes, flagellates and coccolithophores. 


\subsection{Nutrient analysis}

Samples for nutrient determination were collected from the surface and selected depths and kept frozen until analysis. In the laboratory, samples were thoroughly thawed and filtered through cellulose acetate membrane filters. All of the samples were processed according to the recommendations in Strickland and Parsons (1972). Ammonium was measured by using the method determined by Koroleff (1969), following the modifications in Grasshoff et al. (1983), using absorbance at $630 \mathrm{~nm}$. Nitrite and nitrate were determined through a cadmium column reduction of $\mathrm{NO}_{3}^{-}$to $\mathrm{NO}_{2}^{-}$, with standard curves and calculations made according to Strickland and Parsons (1972). Orthophosphate was measured by its reaction with ammonium molybdate using absorption at $885 \mathrm{~nm}$. Silicate in the form of reactive Si was measured according to Strickland and Parsons (1972) and corrected for sea salt interference, following Aminot and Chaussepied (1983). Absorbance values for all nutrients were measured in a FEMTO ${ }^{\circ}$ spectrophotometer.

\subsection{Satellite data}

Satellite images of both surface Chl- $a$ and temperature were acquired by the Moderate Resolution Imaging Spectroradiometer on NASA's Aqua satellite (MODIS-Aqua) and presented as Level 3 (L3) SMI (Standard Mapped Image) monthly composite images, at $4 \mathrm{~km}$ resolution. Only images from September to March (due to low cloud cover) were analyzed in this study for the period 2002 to 2010.

Monthly composites from daily images of sea ice concentration (spatial resolution of approximately $6 \times 4 \mathrm{~km}$, in a $6.25 \mathrm{~km}$ grid) were obtained from the Advanced Microwave Scanning Radiometer (AMSR-E-Aqua). The Artist Sea Ice (ASI) algorithm was applied, which uses an empirical model to retrieve ice concentration between $0 \%$ and $100 \%$ (Spreen et al., 2008). For each monthly image, ice edge was considered to be the location where sea ice concentration was $\leq 15 \%$, as identified by the ASI algorithm (Marrari et al., 2008; Spreen et al., 2008). The sea ice area was then determined based on pixels with a sea ice concentration $>15 \%$.

Ice cover images (AMSR-E) were analyzed for each month during the study period, as the signal from microwave scatterometers does not encounter interference from the atmospheric attenuation. Time series analyses consisted of the synoptic mean of each variable in the area located within $62.0-63.5^{\circ} \mathrm{S}$ and $56.0-61.0^{\circ} \mathrm{W}$ (see Fig. 5).

\subsection{Statistical analysis}

Canonical correspondence analysis (CCA) was performed for the 2003, 2004, 2008 and 2009 cruises. This analysis allows for an evaluation of the main patterns of community variability, as influenced by environmental variables, as well as the main pattern in the weighted means of each species (or group) with respect to the environmental variables (ter Braak and Prentice, 1988). For this analysis, only stations where both biotic and environmental data were available have been considered, totalizing a set of sixty-two cases. Biotic variables were represented by abundances of the main phytoplankton taxonomic groups derived from microscopic analysis. Environmental variables included surface temperature, salinity, dissolved inorganic nitrogen (DIN: nitrate, nitrite and ammonium), phosphate, silicate, UMLD, stability, along with the total and fractionated Chl- $a$ ["nanoplankton" $(<20 \mu \mathrm{m})$ and microplankton $(>20 \mu \mathrm{m})]$. All variables were logtransformed prior to the analysis in order to reduce the influence of the different scales on the sets of variables. In order to test for the significance of the CCA, Monte-Carlo tests were run based on 499 permutations under a reduced model $(p<0.05)$. The first two significant canonical roots were used to produce an ordination diagram. Canonical roots are the weighted sums of phytoplankton variables, which are used to calculate the position of the stations in the diagram, according to their phytoplankton group composition and abundance. Thus, distances between the stations in the ordination diagram reflect the similarity of their phytoplankton assemblages (ter Braak, 1994). Canonical factor loadings are the simple correlations between the environmental variables and canonical roots and are considered as a measurement of the importance of the different environmental variables in determining phytoplankton variability within the study area.

In order to detect temporal correlations between the signals of sea surface temperature (SST), sea surface Chl- $a$ (SSC) and sea ice area, a cross-correlation analysis was applied. This technique allows for a detection of common periodicities between two signals of interest. The cross-correlation coefficient $\left(r_{x y}\right)$ of the two time series $x$ and $y$, each with $n$ data points is determined by $r_{x y}(k)=\frac{c_{x y}(k)}{\sigma_{x} \sigma_{y}}$ [modified from Chatfield (1984)], where $x$ and $y$ are the two time series, $k$ is the lag time, $c_{x y}$ is the covariance coefficient and $\sigma$ is the standard deviation of time series. The covariance coefficient $\left(c_{x y}\right)$, in turn, is defined by: $c_{x y}(k)=\frac{1}{p} \sum_{t_{\mathrm{n}}}^{t_{0}}\left[\left(x_{t}-\bar{x}\right)\left(y_{t+m}-\bar{y}\right)\right]$ for $t_{0}=1$ to $t_{n}=P-1$ and $m=0$,
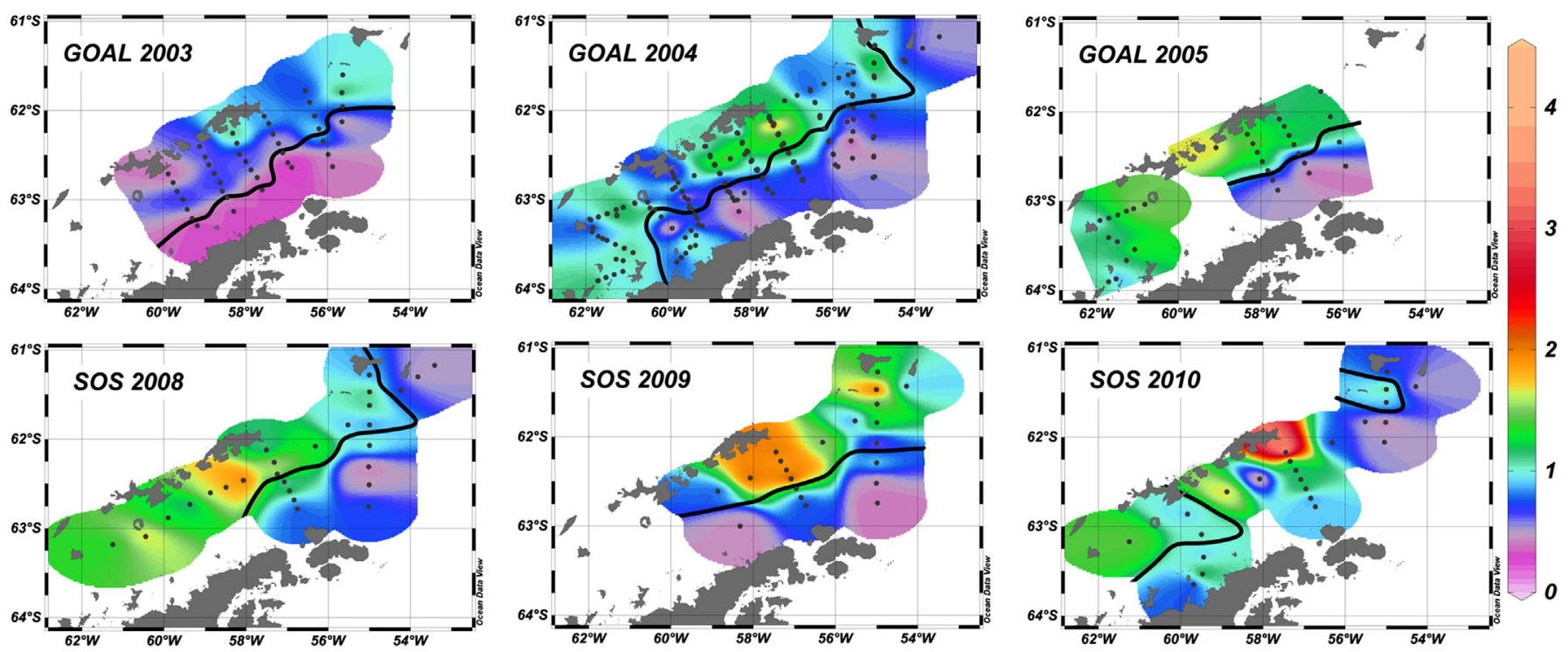

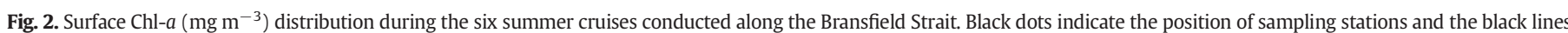
represent the $0.9{ }^{\circ} \mathrm{C}$ isotherm, which separates the TWW (southeast) and TBW (northwestern). 

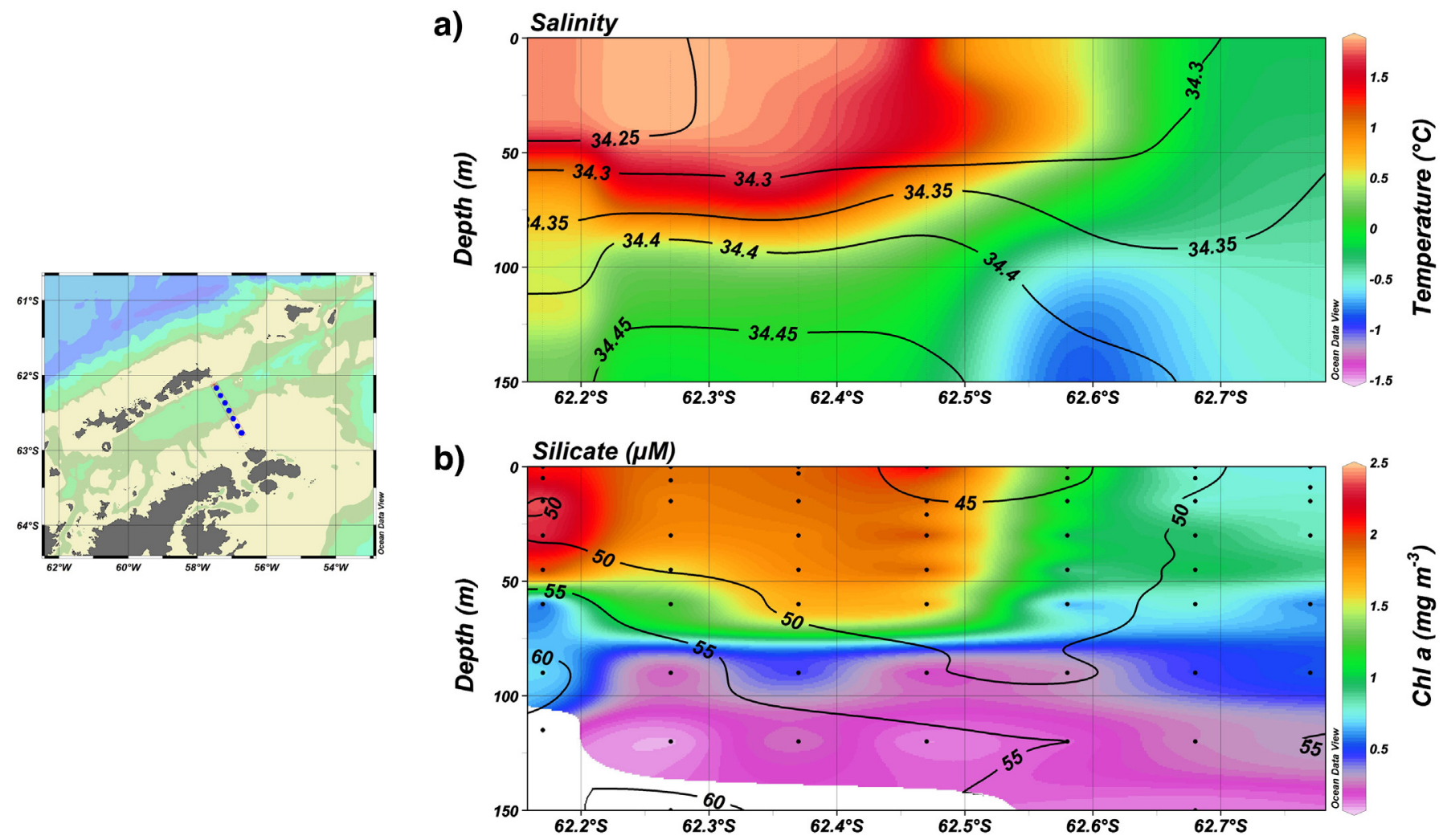

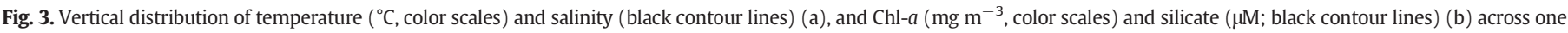

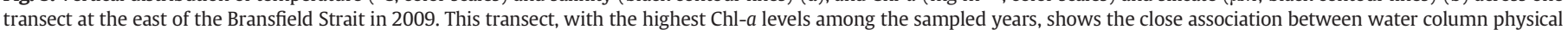

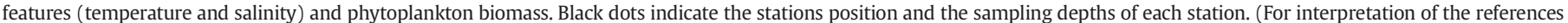
to color in this figure legend, the reader is referred to the web version of this article.)

considering positive values of $k$ and $c_{x y}(k)=\frac{1}{p} \sum_{t_{n}}^{t_{0}}\left[\left(y_{t}-\bar{y}\right)\left(x_{t+m}-\bar{x}\right)\right]$ for $t_{0}=1$ to $t_{n}=P+1$ and $m=-1$, considering negative values of $k$. $P$ is the total number of observations in the series and $t$ is the time unit.

\section{Results}

\subsection{Physical and chemical properties}

Two different water types were found in the surface layer within the study area (Fig. 2), according to the results presented by Sangrà et al. (2011) and López et al. (1999): a colder and more saline TWW, occupying primarily the southeastern sector of the Strait, and a warmer and fresher TBW within the northwestern domain, which were significantly different in temperature and salinity (Kruskal-Wallis test $\mathrm{H}, \mathrm{p}<0.05$ ). The lowest temperature (generally lower than $1{ }^{\circ} \mathrm{C}$ ) and salinity (33.3) levels were observed in 2010, when the region was predominately under the influence of TWW waters (Table 1). In this work, the TWW and TBW were separated by the $0.9{ }^{\circ} \mathrm{C}$ isotherm, depicting the shallow (from surface to ca. $100 \mathrm{~m}$ ) Peninsula Front (PF) (Sangrà et al., 2011) (Figs. 2 and 3), which is located close to the AP.

Vertical density profiles, UMLD and water column stability data for all of the occupied stations during each of the cruises demonstrated three distinct types of water column structure: stations with shallow UMLD $(<50 \mathrm{~m}$ ), stations with deep UMLD (generally $>50 \mathrm{~m}$ ) and stations with homogeneous/well-mixed profiles. In general, stations under TBW influence (Fig. 4) were represented by shallow UMLD $(<50 \mathrm{~m})$ and strong pycnocline (typically $\left.>2000 \times 10^{-8} \mathrm{rad}^{2} \mathrm{~m}^{-1}\right)$. Stations under TWW influence were represented by deep UMLD or even a homogeneous water column (Fig. 3), associated with the lowest stability values which were significantly different from the TBW stations
(Kruskal-Wallis test $\mathrm{H}, \mathrm{p}<0.05$ ). Finally, a small number of stations (4 stations in all cruises) located close to the SSI presented a very shallow upper mixed layer $(<20 \mathrm{~m})$ with higher stability.

The surface distribution of nutrients in the BS (Table 2 ) showed that, in general, mean DIN and silicate levels were relatively high on all cruises across the studied years, with the highest values in 2010 (reaching up to $39.98 \mu \mathrm{M}$ and $71.6 \mu \mathrm{M}$, for DIN and silicate, respectively). However, there was no marked pattern in the horizontal distribution of any nutrient, with them being predominately homogeneously distributed ( $p>0.05$; not shown). Silicate concentration was particularly high in 2004 and 2010, reaching up to $92.0 \mu \mathrm{M}$. Phosphate levels were mostly $>1 \mu \mathrm{M}$ in surface waters. When comparing the similarity between nutrient levels through the different water domains, no significant difference was found between the concentration of the three nutrients (DIN, phosphate and silicate) in the TBW and TWW on any of the cruises (Kruskal-Wallis test H, p > 0.05).

\subsection{Spatial distribution patterns of phytoplankton}

Since surface Chl- $a$ was significantly related to $50-\mathrm{m}$ integrated Chl- $a\left(\mathrm{y}=35.89 \mathrm{x}+18.25, \mathrm{r}^{2}=0.65, \mathrm{p}<0.05\right)$ and appeared to be $\mathrm{a}$ good index of the phytoplankton biomass through the upper $50-\mathrm{m}$ layer, only surface Chl- $a$ data is presented here. Except for a few stations, deep Chl- $a$ maximum (DCM) layers were not detected in vertical Chl- $a$ profiles in the BS (not shown). In 2003, 2005, 2008 and 2009, a similar marked pattern of lower Chl- $a$ at stations near to the AP under TWW influence was observed, while stations under TBW influence presented higher Chl- $a$ (Kruskal-Wallis test $\mathrm{H}, \mathrm{p}<0.05$ ) (see Fig. 2). In 2010, the Strait primarily demonstrated waters dominated by the TWW, with no marked pattern of Chl- $a$ following the distribution of transitional waters. At the same time, the highest Chl- $a$ was found at a station near to the SSI under the lowest salinity 
a)

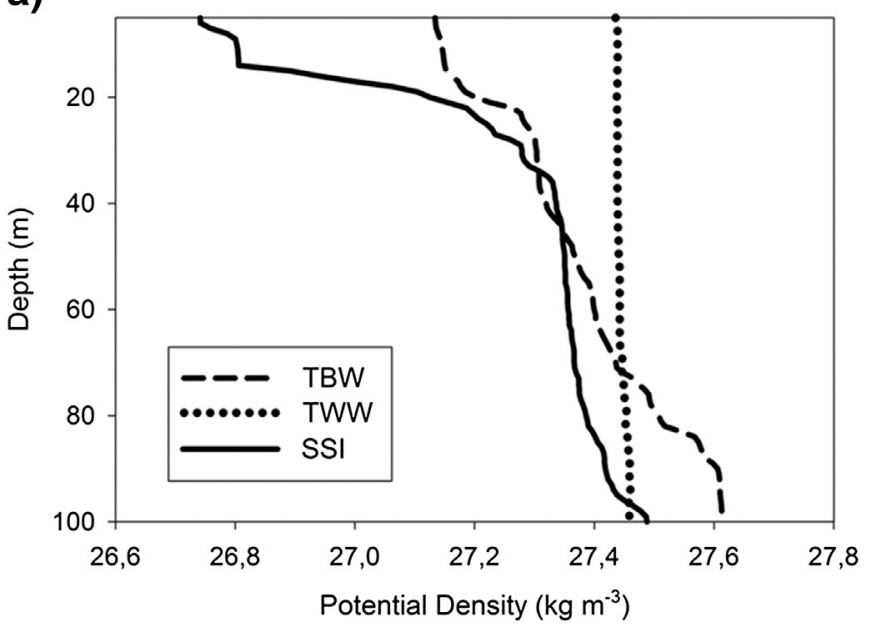

b)

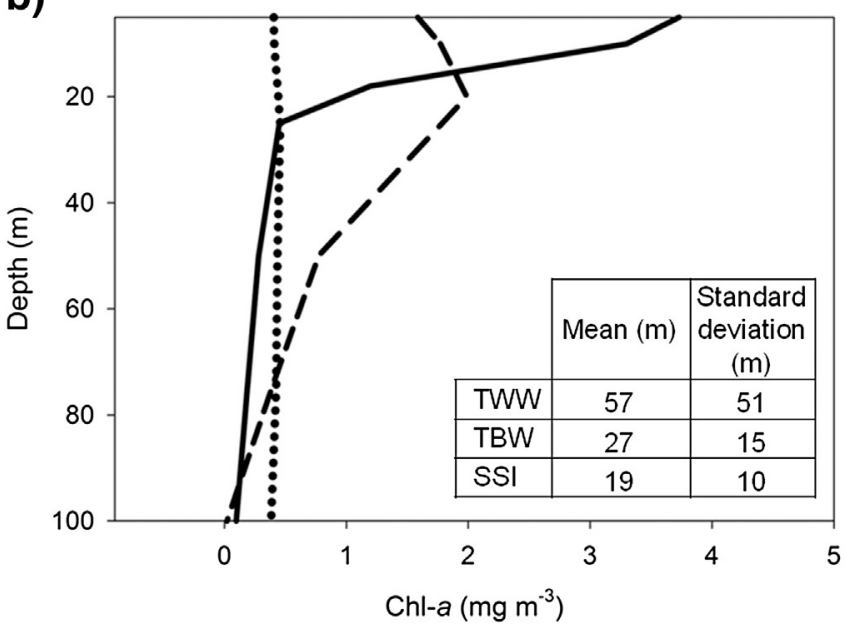

Fig. 4. Typical vertical profiles of potential density $\left(\mathrm{kg} \mathrm{m}^{-3}\right)$ (a) and Chl- $a\left(\mathrm{mg} \mathrm{m}^{-3}\right)$ (b) for stations under the influence of the TBW (dashed line) or TWW (dotted line), and stations close to the South Shetland Islands (SSI, solid line). Inset table in (b) displays the average UMLD (m) and SD (m) for the TBW, TWW and SSI.

level (see Fig. 2). A coupling between phytoplankton biomass and water mass distribution was evidenced by a direct relationship between Chl- $a$ and both temperature $\left(\mathrm{y}=0.18 \mathrm{x}+0.71 ; \mathrm{r}^{2}=0.35\right.$; $\mathrm{p}<0.05)$ and stability $\left(\mathrm{y}=0.00096 \mathrm{x}+0.58 ; \mathrm{r}^{2}=0.51 ; \mathrm{p}<0.01\right)$, with the highest Chl- $a$ levels associated with the warmer and well stratified TBW.

MODIS Chl- $a$ images (Fig. 5) showed a higher Chl- $a$ belt (generally $>1 \mathrm{mg} \mathrm{m}^{-3}$ ) surrounding the SSI during each of the studied summers. However, this Chl- $a$ belt was particularly strong in February 2005 (reaching values $>6 \mathrm{mg} \mathrm{m}^{-3}$ ), and coincided with a relatively low ice cover (black pixels on the images). By contrast, ice cover was more extensive during the December-March period of 2002-2003, 2003-2004 and 2009-2010, which were associated with relatively low Chl- $a$ (generally around $1 \mathrm{mg} \mathrm{m}^{-3}$ ).

Surface distribution of size-fractionated Chl- $a$ showed that the "nanoplankton" fraction $(<20 \mu \mathrm{m})$ was dominant in almost all of the sampling stations (Fig. 6). This fraction represented, on average, $79 \%$, $84 \%, 93 \%$ and $40 \%$ of the total Chl- $a$ in 2003, 2004, 2008 and 2009, respectively. The fraction of the microplankton biomass $(>20 \mu \mathrm{m})$, however, was more elevated in the northwest of the Strait, particularly near to the SSI and Elephant Island, particularly during the 2003 and 2009 cruises (Fig. 6).

The phytoplankton community was intermittently distributed, with an alternating predominance in cell numbers between nanoplanktonic flagellates and microplanktonic diatoms (Fig. 7, Table 3). In the 2003 and 2004 cruises, it was observed throughout the entire sampling area that the phytoplankton community was dominated primarily by nanoplanktonic cryptophytes, with abundances higher than $2.5 \times 10^{5}$ cells $\mathrm{L}^{-1}$ in 2003 and $8 \times 10^{5}$ cells $\mathrm{L}^{-1}$ in 2004 . Conversely, microplanktonic diatoms (particularly Corethron pennatum, Thalassiosira spp. and Pseudo-nitzschia sp.) were more abundant in waters under TBW influence, especially near to the SSI during all of the cruises (Fig. 7). The diatom C. pennatum was detected throughout the area and was particularly abundant in 2003 (reaching $0.7 \times 10^{5}$ cells $\mathrm{L}^{-1}$ ), while Thalassiosira spp. dominated in 2004 and Pseudo-nitzschia spp. and Chaetoceros spp. were dominant in the 2009 diatom assemblage. Other representative diatoms on all cruises were Fragilariopsis spp. and other unidentified pennate species. During the 2008 and 2009 cruises, nanoplanktonic cryptophytes were detected only at a few stations. During those periods, phytoplankton communities at low Chl- $a$ stations were dominated by other uniden-

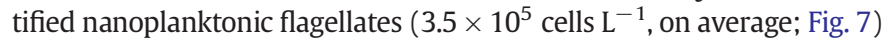
and haptophytes, particularly $P$. antarctica, which were seen as flagellated cells and not as colonies (reaching up to $6 \times 10^{5}$ cells $\mathrm{L}^{-1}$ in 2008, but almost absent in 2009). Dinoflagellates were also detected at lower concentrations, up to $0.9 \times 10^{5}$ cells $\mathrm{L}^{-1}$ in 2008 and $0.2 \times 10^{5}$ cells $\mathrm{L}^{-1}$ in 2009 (not shown). This group was primarily represented by Gymnodinium spp., Gyrodinium spp. and Prorocentrum spp. Coccolithophores presented a minor contribution to the phytoplankton community in the surveyed area (not shown), with cell numbers lower than $10 \%$ of total cell counts on all cruises. Only at station 7 (2003 cruise) did they contribute to $34.5 \%$ of the phytoplankton cell abundance. The Kruskal-Wallis' H-test that was applied to assess differences in phytoplankton communities between TBW and TWW stations showed that only diatoms were present at significantly $(\mathrm{p}<0.05)$ higher concentrations in the TBW.

\subsection{Relationship between the phytoplankton communities and oceanographic features}

The response of the phytoplankton community to environmental variability was investigated using a canonical correspondence analysis (CCA) (Table 4 and Fig. 8). A Monte-Carlo permutation test of F-ratio,

Table 2

Mean $( \pm$ SD) surface nutrient values $(\mu \mathrm{M})$ for stations under TBW and TWW influence for all cruises. DIN $=$ nitrate + nitrite + ammonium.

\begin{tabular}{|c|c|c|c|c|c|c|}
\hline \multirow[t]{2}{*}{ Cruise } & \multicolumn{2}{|l|}{ DIN } & \multicolumn{2}{|l|}{ Phosphate } & \multicolumn{2}{|l|}{ Silicate } \\
\hline & TWB & TWW & TWB & TWW & TWB & TWW \\
\hline GOAL 2003 & $24.71( \pm 6.84)$ & $22.73( \pm 3.97)$ & $1.86( \pm 0.97)$ & $2.40( \pm 0.85)$ & $53.66( \pm 7.07)$ & $46.25( \pm 9.79)$ \\
\hline GOAL 2004 & $26.62( \pm 4.68)$ & $26.87( \pm 5.55)$ & $1.82( \pm 0.35)$ & $1.96( \pm 0.44)$ & $62.44( \pm 9.55)$ & $62.83( \pm 10.13)$ \\
\hline GOAL 2005 & $18.86( \pm 6.60)$ & $22.89( \pm 4.82)$ & $1.49( \pm 0.57)$ & $1.58( \pm 0.40)$ & $41.51( \pm 10.59)$ & $39.38( \pm 8.85)$ \\
\hline SOS 2008 & $22.92( \pm 3.86)$ & $24.45( \pm 4.47)$ & $0.78( \pm 0.28)$ & $0.86( \pm 0.38)$ & $36.85( \pm 12.70)$ & $51.29( \pm 4.26)$ \\
\hline SOS 2009 & $31.45( \pm 3.39)$ & $34.26( \pm 1.66)$ & $1.81( \pm 0.25)$ & $1.75( \pm 0.21)$ & $47.19( \pm 2.27)$ & $46.54( \pm 3.87)$ \\
\hline SOS 2010 & $39.69( \pm 5.06)$ & $40.10( \pm 3.78)$ & $1.86( \pm 0.05)$ & $1.97( \pm 0.22)$ & $64.91( \pm 9.01)$ & $74.27( \pm 8.64)$ \\
\hline
\end{tabular}



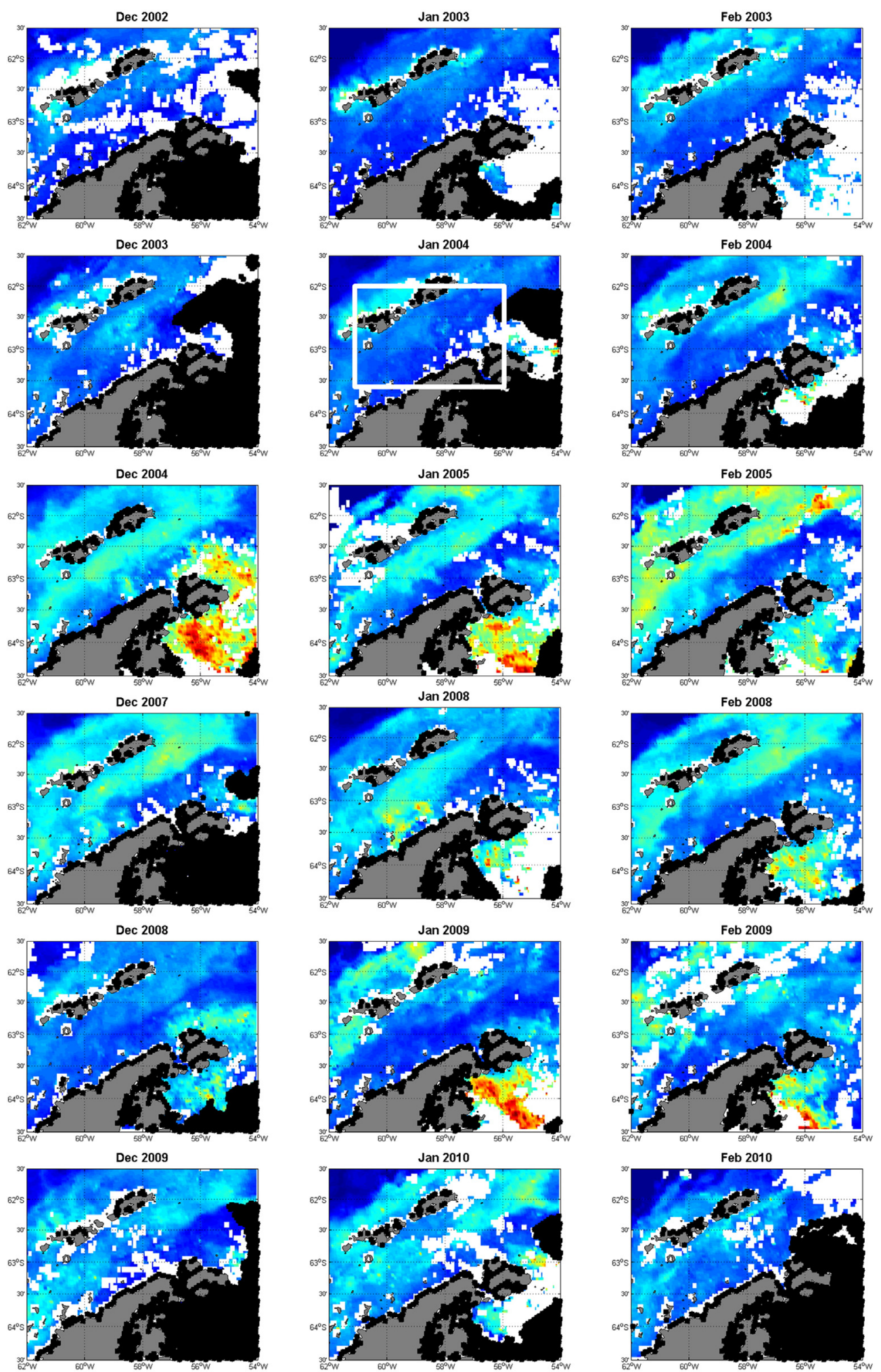

0.1

Chlorophyll a concentration $\left(\mathrm{mg} \mathrm{m}^{3}\right)$

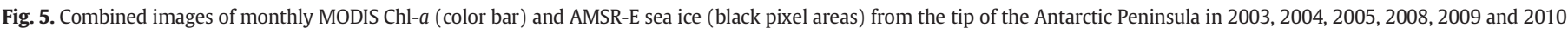

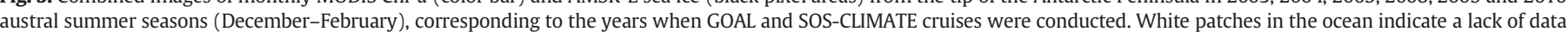

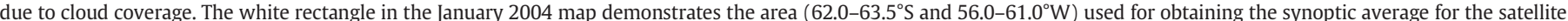
time series analysis. (For interpretation of the references to color in this figure legend, the reader is referred to the web version of this article.) 

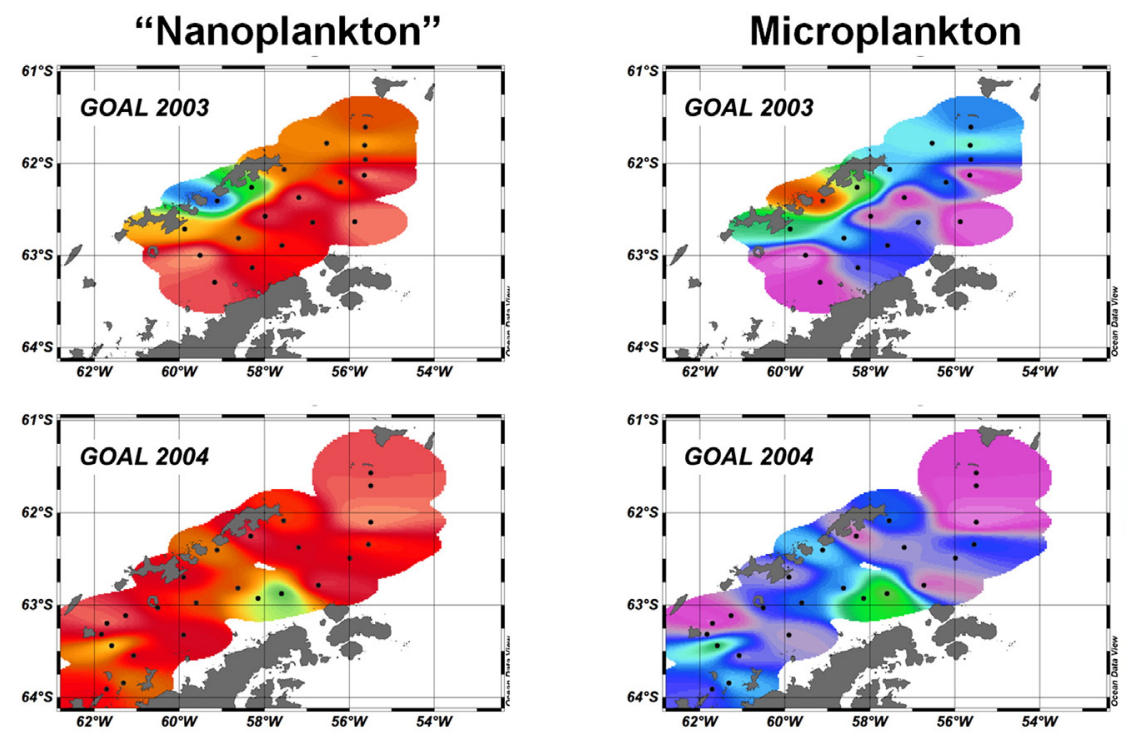

$80 \%$
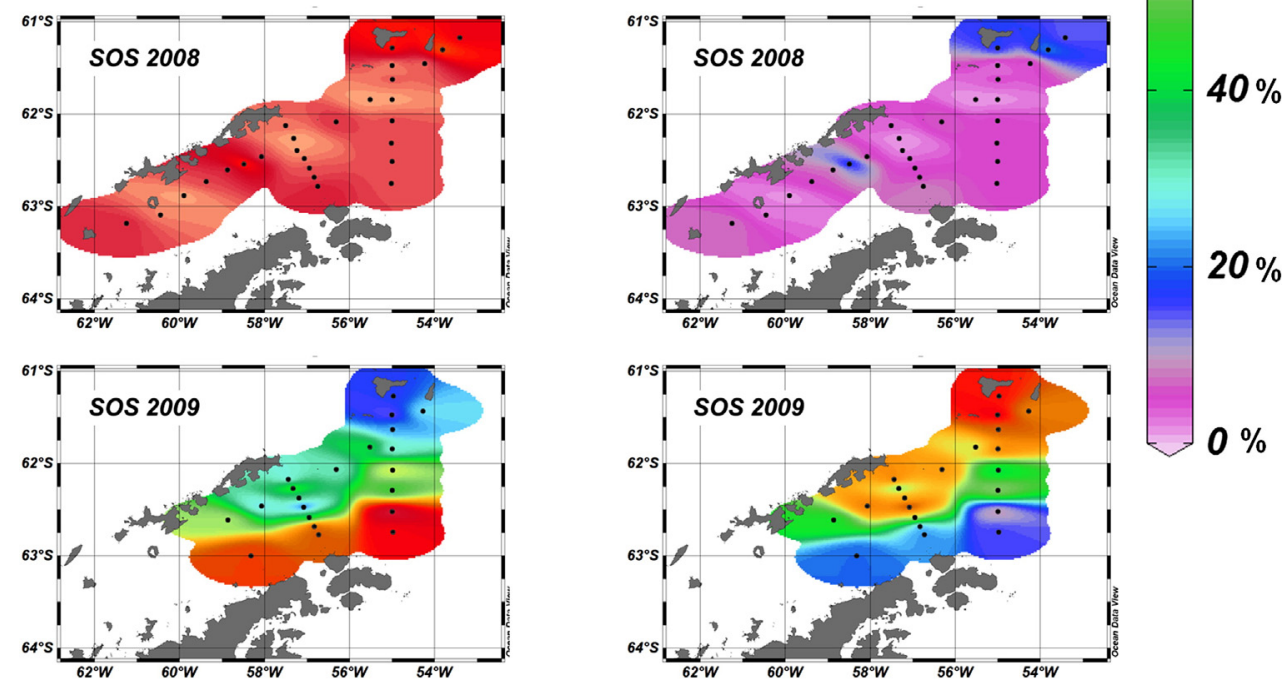

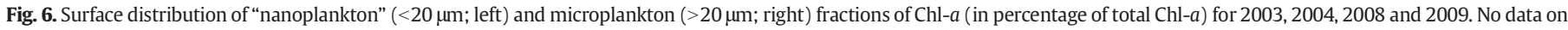
fractionated Chl- $a$ is available for 2005 and 2010.

applied to the analysis, showed that the environmental variables (temperature, salinity, DIN, phosphate, silicate, UMLD, stability, total Chl- $a$, and "nanoplankton" and microplankton fractions of Chl-a) reasonably explained (61\%) the spatial distribution variability of phytoplankton groups $(\mathrm{p}<0.01)$. The first two significant canonical roots cumulatively explained $60.9 \%$ of the observed variance. The first canonical root (58.3\% of the variation explained) clearly distinguished the phytoplankton species/groups of the 2004 cruise, which presented higher silicate concentration and the lowest salinity values in the study region (Fig. 8). However, during this cruise, there was no clear spatial distribution pattern in both total Chl- $a$ and phytoplankton community (either groups or size classes) in relation to the main surface waters (TWW and TBW), in comparison with the other sampling years (see Figs. 6 and 7). Although the second canonical root explained only $2.2 \%$ of the variation, it resolved the separation of stations according to their relation with temperature, total Chl- $a$ and the microplanktonic fraction of Chl- $a$ from the opposite stations associated with salinity, UMLD and the "nanoplanktonic" fraction of Chl- $a$ (see Fig. 8 and factor loadings in Table 4). Additionally, although the third canonical root explained only $0.4 \%$ of the variation, it indicates an inverse relationship between Chl- $a$ and DIN. Higher factor loadings were found for temperature, salinity and Chl- $a$ variables, which reflected a strong association between phytoplankton biomass variability and the distribution of the transitional waters. Other important variables that contributed to explain phytoplankton variability were UMLD and stability, with factor loadings relatively similar to those for temperature and salinity. The second canonical root could also be interpreted as indicating a gradual change in phytoplankton structure from stations under the influence of the TWW, to stations under the influence of the TBW. These latter stations showed a diatom-dominated community, positively associated with total Chl- $a$, microplanktonic Chl- $a$ and temperature (Fig. 8), particularly during the 2009 summer. In contrast, TWW influenced stations appeared to be related to salinity, UMLD and "nanoplankton", represented by cryptophytes, haptophytes and other unidentified flagellates (Fig. 8). These organisms combined attained high cell abundance in the summers of 2003, 2004 and 2008. Furthermore, Chl- $a$ presented a significant $(\mathrm{p}<0.05)$ positive correlation with microplanktonic Chl- $a$, stability and temperature and a negative $(\mathrm{p}<0.05)$ correlation with salinity during each of the sampled years (data not shown), which reflected the strong association between the distribution of transitional waters along the BS and phytoplankton biomass and size class structure.

\subsection{Interannual analysis}

Time series of satellite data (Fig. 9) displayed the interannual variability of the three variables: sea surface Chl-a (SSC), sea 
a)

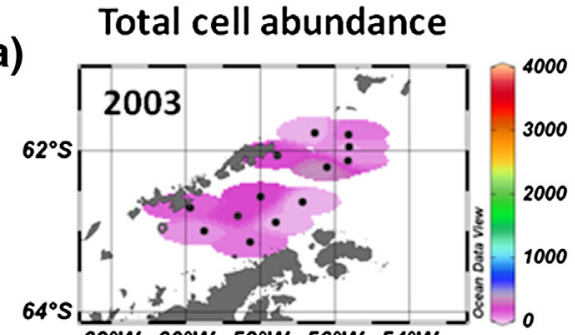

$62^{\circ} \mathrm{W} 60^{\circ} \mathrm{W} 58^{\circ} \mathrm{W} \overline{56^{\circ} \mathrm{W}} \overline{54^{\circ} \mathrm{W}}$

Total cell abundance

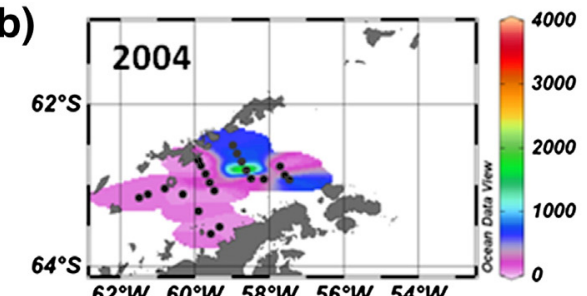

$62^{\circ} \mathrm{W} 60^{\circ} \mathrm{W} \overline{58^{\circ} \mathrm{W}} \overline{56^{\circ} \mathrm{W}} \overline{54^{\circ} \mathrm{W}}$

c)

Total cell abundance

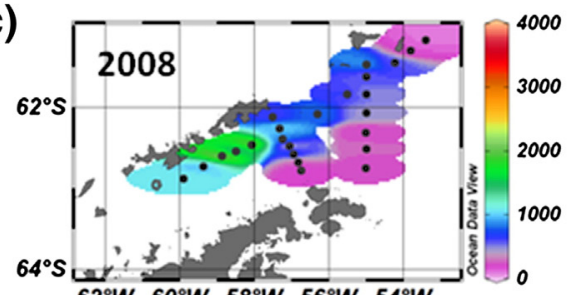

$62^{\circ} \mathrm{W} 60^{\circ} \mathrm{W} \overline{58^{\circ} \mathrm{W}} \overline{56^{\circ} \mathrm{W}} \overline{54^{\circ} \mathrm{W}}$

d)

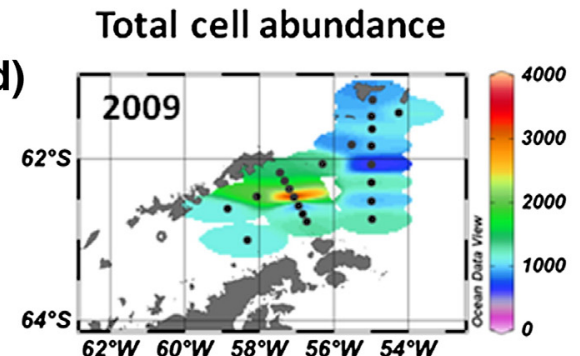

Diatoms

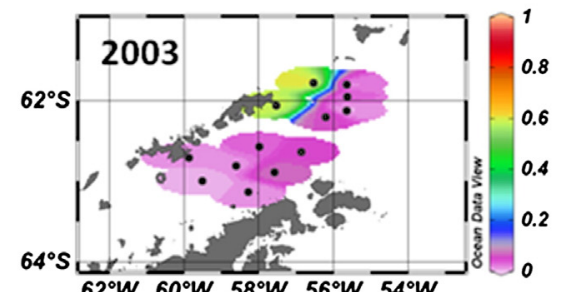

$62^{\circ} \mathrm{W} 60^{\circ} \mathrm{W} 58^{\circ} \mathrm{W} 56^{\circ} \mathrm{W} 54^{\circ} \mathrm{W}$

Diatoms

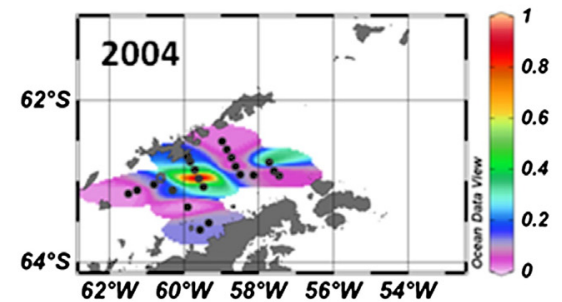

Diatoms

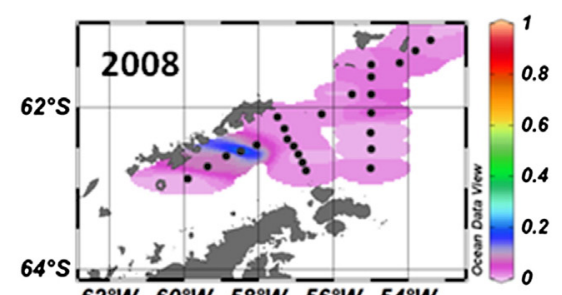

$62^{\circ} \mathrm{W} 60^{\circ} \mathrm{W} \overline{58^{\circ} \mathrm{W}} \overline{56^{\circ} \mathrm{W}} \overline{54^{\circ} \mathrm{W}}$

Diatoms

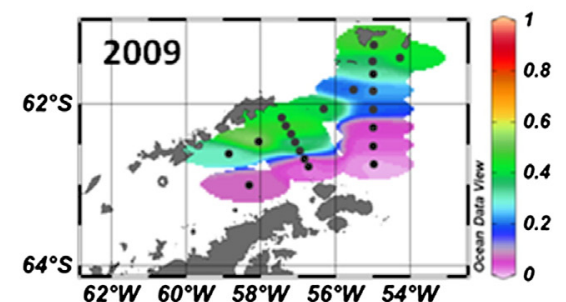

Flagellates

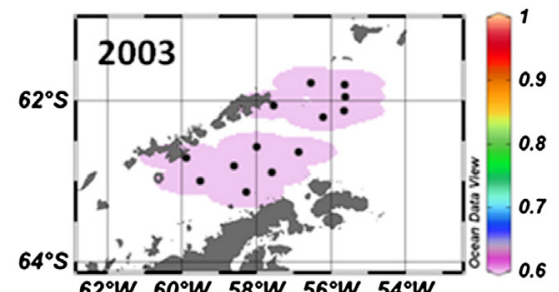

Flagellates

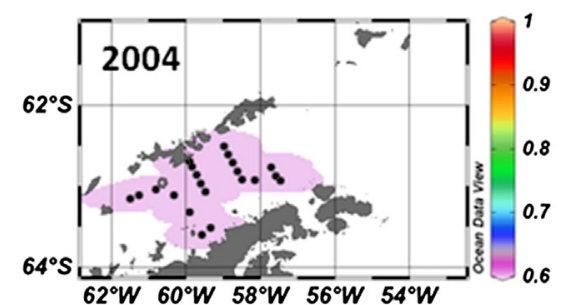

Flagellates

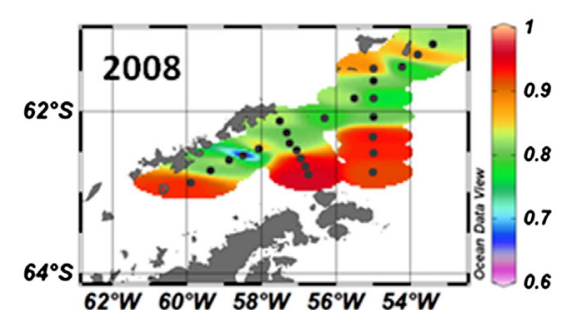

Flagellates

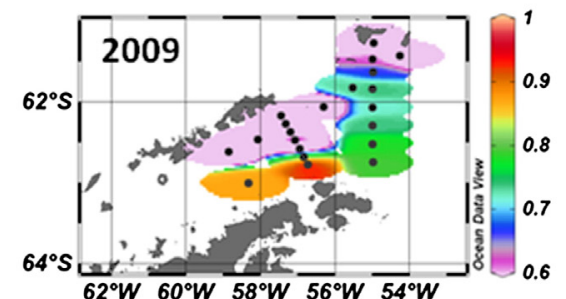

\section{Cryptophytes}

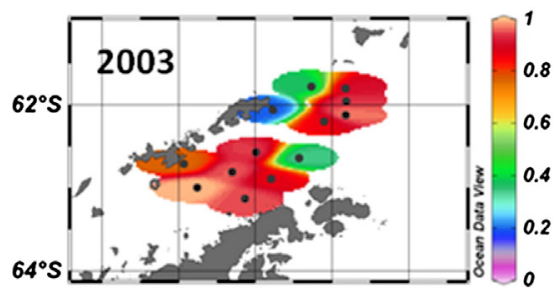

$62^{\circ} \mathrm{W} 60^{\circ} \mathrm{W} 58^{\circ} \mathrm{W} \overline{56^{\circ} \mathrm{W}} \overline{54^{\circ} \mathrm{W}}$

\section{Cryptophytes}

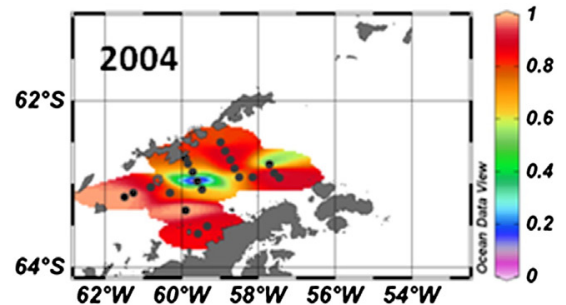

\section{Cryptophytes}

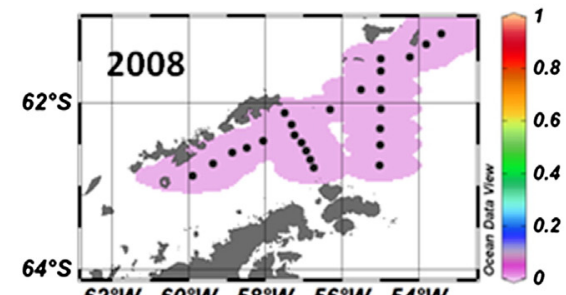

$62^{\circ} \mathrm{W} 60^{\circ} \mathrm{W} \overline{58^{\circ} \mathrm{W}} \overline{56^{\circ} \mathrm{W}} \overline{54^{\circ} \mathrm{W}}$

\section{Cryptophytes}

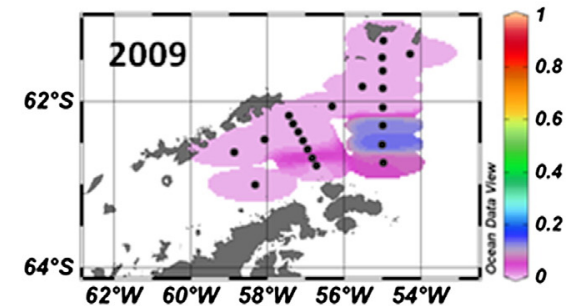

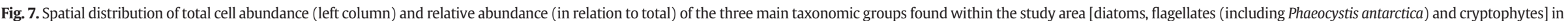
2003 (a), 2004 (b), 2008 (c) and 2009 (d). No data is available for 2005 and 2010. 
Table 3

Abundance ranges (minimum and maximum, cells $\mathrm{L}^{-1}$ ) of the main phytoplankton taxa on four cruises (2003, 2004, 2008 and 2009) to the Bransfield Strait. ND: not detected.

\begin{tabular}{|c|c|c|c|c|}
\hline Species & 2003 & 2004 & 2008 & 2009 \\
\hline Corethron pennatum & ND-70,000 & ND-10,000 & ND-560 & ND-4220 \\
\hline Pseudo-nitzschia spp. & ND-14,000 & ND-35,000 & ND-130,000 & ND-410,000 \\
\hline Chaetoceros spp. & ND & ND & ND & $1800-360,000$ \\
\hline Thalassiosira spp. & ND-5000 & ND-300,000 & ND-1400 & $170-57,000$ \\
\hline Gymnodiniaceae & ND-3000 & ND-1000 & $4100-75,000$ & $3500-27,000$ \\
\hline Gyrodinium spp. & ND-1000 & ND-7000 & $670-7200$ & $2000-11,500$ \\
\hline Prorocentrum minimum & ND-2000 & ND & ND-10,000 & $450-22,500$ \\
\hline Unidentified flagellates & ND-30,000 & ND-200,000 & $27,000-345,000$ & $116,000-1,169,191$ \\
\hline Phaeocystis antarctica & ND & ND & $14,000-665,000$ & ND-365,000 \\
\hline Coccolithophores & ND-6000 & ND-60,000 & ND-50,000 & ND-69,000 \\
\hline Crytophyceae & $1000-300,000$ & $600-2,000,000$ & ND & ND-79,000 \\
\hline Pyramimonas sp. & ND-30,000 & ND-200,000 & ND & ND \\
\hline
\end{tabular}

surface temperature (SST) and sea ice area. Peaks in SSC (gray bars) were predominately detected in February, while the highest temperatures were observed between January and February during each of the studied years. The sea ice area presented a marked seasonal variability, being inversely related to the other variables, with maximum values observed in July/August and minimum values from January to March. The austral spring/summer of 2005-2006 showed the highest SSC and SST values within the time series (2002-2010), and was associated with the earlier start of the sea ice retreat, which subsequently translated into ice free areas for a longer period when compared to the remaining years of the study. The 2007 winter season appeared to be the coldest, since the lowest temperatures were observed and the sea ice extended more than $2500 \times 10^{2} \mathrm{~km}^{2}$ during a period of over three months (see also Fig. 5).

Cross-correlation analysis between the variables derived from satellite data (Table 5 ) showed the maximum correlations for the zero lag time $(p<0.01)$. This indicates that the response of SSC (either directly or indirectly) to SST and sea ice is most probably within a time scale lower than a monthly-based time series. Taking into account the monthly time resolution and the maximum correlations for the zero lag time, the three variables appeared to be in phase. The sea ice area was inversely related with both SSC and SST $\left(r_{x y}=-0.53\right.$ and $r_{x y}=-0.75$, respectively; lag $\left.=0 ; \mathrm{p}<0.01\right)$, while SSC was directly related to SST (Table 5). Nevertheless, a visual analysis of the data set (see Table 1 and Figs. 2, 5, 6 and 7) revealed correlations between low UMLD and high stability with the enhancement of Chl- $a$ (averages higher than $1.35 \mathrm{mg} \mathrm{m}^{-3}$ ), which were associated with the dominance of microplanktonic diatoms within the TBW. In particular, this was observed in 2008 and 2009, when the TBW showed an average UMLD of $49 \mathrm{~m}$ and $61 \mathrm{~m}$, and stability levels of about $8500 \times 10^{-8} \mathrm{rad}^{2} \mathrm{~m}^{-1}$ and $3300 \times 10^{-8} \mathrm{rad}^{2} \mathrm{~m}^{-1}$ (see Table 1 ), respectively.

Table 4

Factor loadings (correlation coefficients) of environmental variables for the first three canonical roots as estimated through canonical correspondence analysis.

\begin{tabular}{lccc}
\hline Parameter & 1st canonical root & 2nd canonical root & 3rd canonical root \\
\hline Temperature & -0.092 & 0.693 & -0.252 \\
Salinity & -0.437 & -0.244 & -0.077 \\
DIN & -0.102 & 0.226 & 0.011 \\
Phosphate & 0.457 & 0.229 & 0.159 \\
Silicate & 0.486 & 0.193 & 0.022 \\
Chl- $a$ & 0.579 & 0.503 & -0.019 \\
Chl- $a$ small (nano) & -0.448 & -0.214 & -0.018 \\
Chl- $a$ (micro) & -0.196 & 0.794 & -0.018 \\
UMLD & -0.495 & -0.131 & 0.204 \\
Stability & -0.339 & -0.174 & -0.04
\end{tabular}

\section{Discussion}

\subsection{Phytoplankton and environmental factors: spatial variability}

Both the TBW and TWW (López et al. (1999)] were the major surface waters within the BS (see Figs. 2 and 3), as previously described by several authors (García et al., 2002; López et al., 1999; Sangrà et al., 2011). These contrasting, transitional waters were previously shown to generate a noticeable, physical gradient across the $\mathrm{BS}$, composed by the Peninsula Front (close to the AP), the Bransfield Front (close to the SSI) and an inter-frontal anticyclonic eddy field between those fronts (e.g. Sangrà et al., 2011, 2014). Although the presence of such oceanographic features has been reported within the BS, particularly with an emphasis on their influence on phytoplankton community structure variability (Sangrà et al., 2014), only the Peninsula Front was identified in the present work. The inability to observe both the Bransfield Front and mesoscale anticyclonic eddies in this work could be as a result of the low spatial resolution coverage that exceeded the mean local first baroclinic Rossby radius

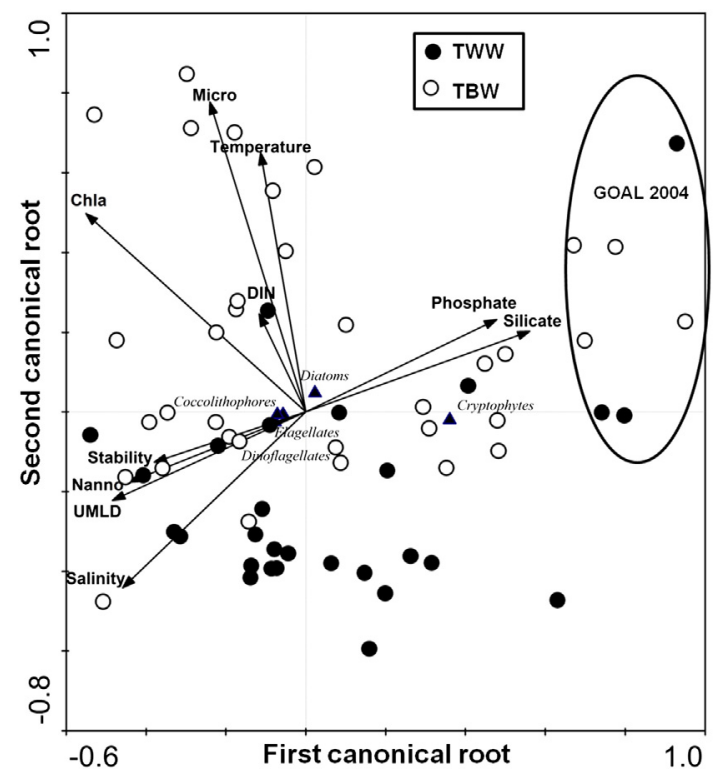

Fig. 8. Canonical correspondence analysis ordination diagram relative to data on surface abundance of phytoplankton. The first two significant canonical roots represent $60.5 \%$ of phytoplankton groups-environment relationships. Arrows refer to environmental variables (note that micro and nano correspond to the microplankton and "nanoplankton" fractions of Chl- $a$, respectively). Triangles refer to surface absolute abundance of major species/groups. Sampling stations, (where all data were available) are represented by circles, as follows: stations under TWW (black) and TBW (white) influence. Circled dots represent stations from GOAL-2004 cruise. 


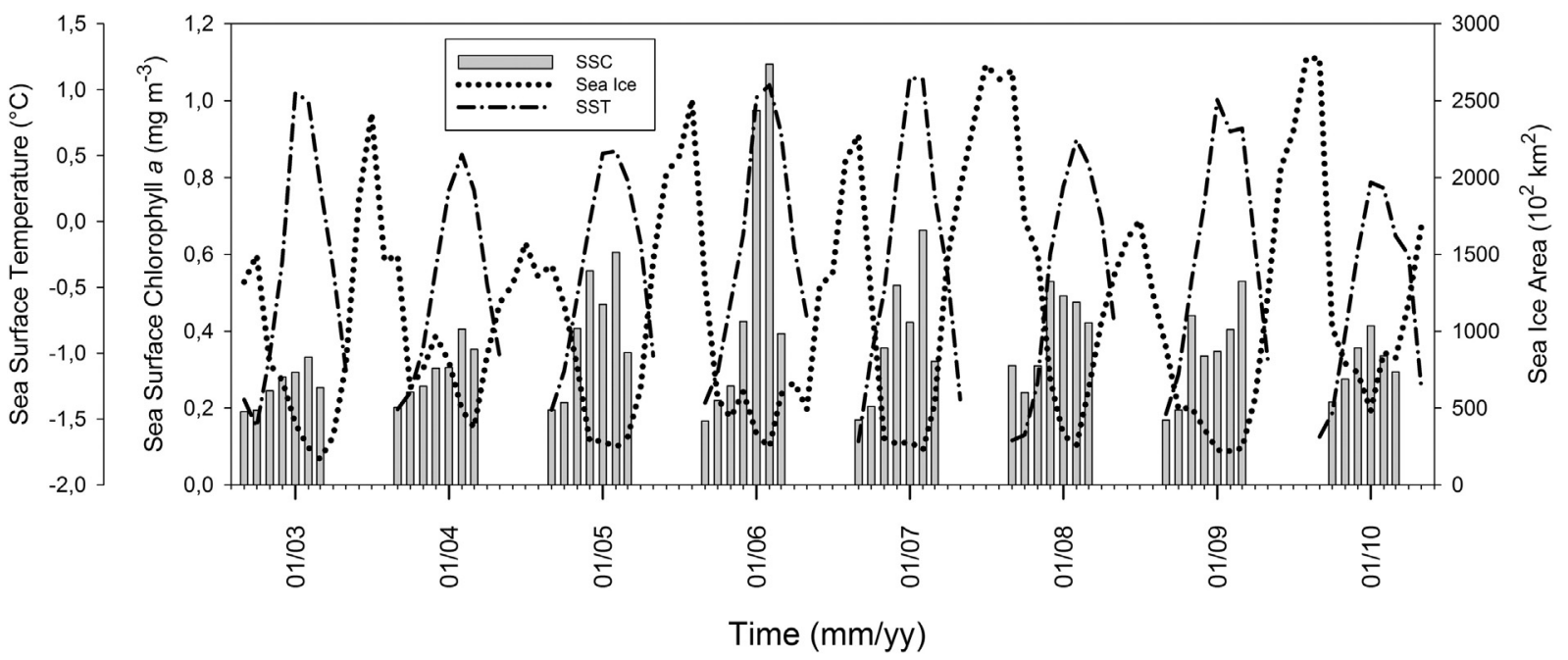

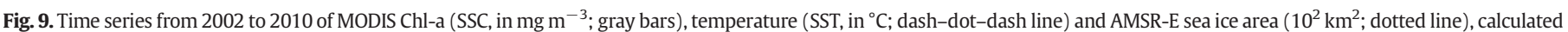

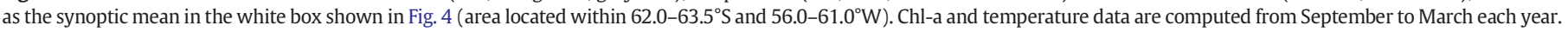

of deformation (Rd) ( $10 \mathrm{~km}$; Chelton et al. 1998). Therefore, the mesoscale variability could not be resolved within the sampling transects.

The dynamics of phytoplankton biomass along the BS have been previously shown to be resolved across a salinity gradient that separates the co-limiting conditions of either deep UMLD (i.e. light-controlled condition) or low iron concentration, including the sites of the Antarctic Circumpolar Current in the Drake Passage (Hewes et al., 2009). In the present work, a salinity gradient was also observed across the BS and was negatively correlated $(\mathrm{p}<0.05)$ with Chl- $a$ for each sampled year. In a similar way, the pattern of enhanced Chl- $a$ in the northern sector of the BS demonstrated the coupling between water column structure and phytoplankton biomass: a shallow (deep) UMLD and high (low) Chl- $a$ in the TBW (TWW). This type of association has been pointed out in other studies conducted within the BS and also at other sites across the Southern Ocean (Alderkamp et al., 2012; Castro et al., 2002; Hewes et al., 2009; Mura et al., 1995). Sangrà et al. (2011) also demonstrated that sites within TWW influence presented deep UMLD or even a homogeneous water column with the lowest stability values. A similar Chl- $a$ gradient between the northern and southern sectors of the BS was also detected during the AMLR (Antarctic Marine Living Resources) sampling program from late February to March 2004 (Hewes et al., 2008). Lower Chl- $a$ in the southern BS has been attributed to the surface flow of oligotrophic Weddell Sea waters toward the AP (Holm-Hansen and Hewes, 2004; Zhou et al., 2002). In the present study, three types of vertical density profiles were observed (see Fig. 4). The scenario observed from the profiles suggested that a few of the stations close to the SSI (very shallow UMLD and higher Chl- $a$ ) could have been attributed to sea ice melting, as discussed in Holm-Hansen and Hewes (2004) and Holm-Hansen et al. (2004).

Dissolved macronutrient concentrations at the surface were high during each of the cruises and were unlikely to have been limiting

Table 5

Cross-correlation coefficient $\left(r_{x y}\right)$, lag time ( $\left.\mathrm{Lag}\right)$ and $p$ value for the satellite data (sea surface temperature "SST", sea ice area and sea surface Chl- $a$ "SSC") obtained from cross-correlation analysis.

\begin{tabular}{llll}
\hline Variables & \multicolumn{1}{c}{$r_{x y}$} & Lag & $\mathrm{p}$ \\
\hline SST $\times$ Sea Ice & -0.75 & 0 & $<0.01$ \\
SST $\times$ SSC & 0.65 & 0 & $<0.01$ \\
Sea Ice $\times$ SSC & -0.53 & 0 & $<0.01$
\end{tabular}

phytoplankton growth (Table 2), indicating that other processes were driving the patchy distribution of surface Chl- $a$ over the study area (see Fig. 2). The Southern Ocean is widely recognized as a high nutrient, low Chl-a zone (HNLC) (Hoppema et al., 2003) in which phytoplankton development is considered to be iron-limited (Boyd et al., 2000; Feng et al., 2010; Martin et al., 1990a,b). As demonstrated in previous studies, variations in both Chl- $a$ and primary production within the Southern Ocean could be associated with environmental factors such as fronts and upwelling (Bathmann et al. 1997; Jacques and Panouse, 1991; Lovenduski and Gruber, 2005), as well as the proximity to the coast or islands (Blain et al. 2001; Comiso et al. 1993; Hoppema et al., 2003), where iron availability is be periodically enhanced. In addition, it has been established that a sunlit, shallow mixed layer depth (Mitchell and Holm-Hansen, 1991; Nelson and Smith, 1991) combined with an iron supply would count as two major factors or co-factors affecting phytoplankton dynamics in the Southern Ocean (Arrigo et al., 1999). Unfortunately, in the present study, there is no data available on iron concentration and, therefore, variations in phytoplankton biomass and composition are predominately described in relation to the physical features of the water column.

The "nanoplankton" fraction (pico- + nanoplankton: $<20 \mu \mathrm{m}$ ) was more abundant than the microplankton fraction, concurring with other studies conducted in the region (García-Muñoz et al., 2013; Hewes et al., 2009; Varela et al., 2002), and it was predominately represented by flagellates: either cryptophytes in the summers of 2003 and 2004 , or a plethora of flagellated forms (including $P$. antarctica) in the summers of 2008 and 2009. Picoplankton contribution was unlikely to have had any major importance during the sampling periods, as these very small forms are generally not a relevant component within the Southern Ocean (Scott and Marchant, 2005), although within the oligotrophic Pacific Antarctic sector this fraction was estimated as 7-33\% of the total phytoplankton biomass (Wright et al., 2009). In our work, a pronounced relative contribution of cryptophytes was primarily associated with lower Chl- $a\left(<1 \mathrm{mg} \mathrm{m}^{-3}\right)$, contrasting other studies that have reported a high abundance of cryptophytes in association with higher Chl- $a\left(>1 \mathrm{mg} \mathrm{m}^{-3}\right)$ at other sites across the BS or in adjacent regions (Mendes et al., 2013; Moline and Prézelin, 1996; Moline et al., 2004; Rodriguez et al., 2002). Moreover, there were noteworthy differences in phytoplankton composition between firstly the 2003 and 2004 cruises, which identified a substantial relative contribution of cryptophytes, and the data sets from the 2008 and 2009 cruises, which observed a prominent presence of other flagellates (see Fig. 7). In 2003 and 2004, phytoplankton assemblages were typical 
of low Chl-a (primarily C. pennatum and cryptophytes), whereas in 2008 and 2009, predominately higher Chl- $a$ was associated with a higher abundance of the diatoms Pseudo-nitzschia spp. (1.3-4.1 $\times 10^{5}$ cells $\mathrm{L}^{-1}$ ), Chaetoceros spp. (up to $3.6 \times 10^{5}$ cells L $^{-1}$, identified only in 2009), gymnodinioid dinoflagellates (between $10^{3}$ and $0.75 \times 10^{5}$ cells $\mathrm{L}^{-1}$ ) and P. antarctica (up to $0.7 \times 10^{6}$ cells $\mathrm{L}^{-1}$ ) (see Table 3 ). Overall, in each of the sampling years and particularly in 2009, the microplanktonic diatoms dominated few stations with high Chl- $a$ in the vicinities of the SSI. This is most probably as a result of recent localized ice melting, leading to the establishment of a shallow UMLD with strong pycnocline and, most likely, iron input, which has been indicated to be relatively high in the vicinities of the SSI (Selph et al., 2013). In fact, other studies have also described distinct regions along the wAP with different $\mathrm{Chl}-a$ ranges associated with typical phytoplankton assemblages: moderate to high Chl- $a$ dominated by cryptophytes, high Chl-a composed mainly of diatoms, and low Chl- $a$ associated with a mixture of diatoms and unidentified phytoflagellates (e.g., Varela et al., 2002). Therefore, phytoplankton along the WAP, including the BS, appears to follow a consistent pattern, associated with environmental conditions (primarily water column structure) that drive biomass (Chl-a) and community composition/structure. Additionally, the spatial variability of phytoplankton groups in the BS could be related to different physiological responses to varying environmental forcing by the two major groups (diatoms and flagellates). Recent works conducted with Ross Sea field samples have shown that these major phytoplankton groups can behave distinctly under varying ambient light and mixed layer depth. For instance, the diatom Fragilariopsis cylindricus tended to be more successful than the haptophyte P. antarctica in sunlit, shallower UML, while $P$. antarctica appeared to present a better physiological performance in deeper UML (Arrigo et al., 2010; Kropuenske et al., 2010; Mills et al., 2010). In the present work, this was not clearly seen, since $P$. antarctica was found in relatively low numbers and was not a conspicuous component of the phytoplankton community.

In general, the CCA ordination diagram (see Table 4 and Fig. 7) showed a strong association between phytoplankton biomass variability and the distribution of transitional waters, as seen through the highest factor loadings displayed by temperature, salinity and Chl-a. Phosphate and silicate presented an inverse relationship with Chl- $a$, suggesting a consumption of these macronutrients by the phytoplankton community. Nevertheless, the levels of all nutrients, as well as N:P and Si:N ratios, suggest that the phytoplankton community was not under any macronutrient limitation. Although the first and second canonical roots have indicated co-variability between DIN and Chl- $a$, the third root separated those parameters, which could be interpreted as DIN also being consumed by phytoplankton. Apart from this, as silicate is not required for cryptophyte growth, the relationship between these organisms and the concentration of silicate was positive in 2004, when those flagellates were numerically prominent. This pattern of association (high silicate levels and predominance of cryptophytes) was also emphasized in the late summer of 2010 in the region (Mendes et al., 2013). Relatively high factor loadings were also obtained for the UMLD and water column stability, which together with the high factor loadings displayed by temperature, salinity and Chl- $a$ confirm the strong influence of the water column physical structure on phytoplankton variability as previously noted by several sources (Mitchell and Holm-Hansen, 1991; Ryabov et al., 2010). The ordination diagram showed an unexpected positive relationship between UMLD and stability; however, an expected inverse relation between those two variables has only become apparent after taking the third canonical root into account (see Table 4). Thus, we can re-affirm that the CCA triplot, together with the analysis of the third canonical root, succinctly portrays the complex relationships between the biological data (our input) and the environmental factors (McGarigal et al., 2000).

\subsection{Interannual variability in phytoplankton, temperature and sea ice area}

Phytoplankton production in the Southern Ocean has been shown to be influenced by the extent of open water area subjected to interannual and seasonal cycles which, in turn, are related to the cycle of sea ice retreating (Arrigo et al., 1999), thus allowing the photosynthetically active radiation to penetrate in the water column. Therefore, the timing of the development and retreat of sea ice are considered as important factors in the temporal variability of phytoplankton communities in the AP (Arrigo et al., 1999; Garibotti et al., 2003, 2005; Moline and Prézelin, 1996). Although the dynamics of sea ice are influenced by winds (Stammerjohn et al., 2003, and references therein), here we related these dynamics only with temperature. In our study, SSC, SST and sea ice area (on a monthly basis) were best correlated considering a zero lag time, according to the cross-correlation analysis (see Table 5). Thus, we can suggest that those variables were interrelated in phase under a monthly time resolution, although sea ice area, as expected, varied inversely in relation to SSC and SST.

The temporal resolution presented in the satellite time series did not unveil the processes regarding the response of phytoplankton (as surface Chl- $a$ ) to the SST and sea ice variability. Those processes potentially display a response within a shorter time lag than our coverage. Even though a significant interannual variability signal was found in our time series, there was a visible relationship between sea ice area and surface Chl- $a$, especially in the December-March period of 2005-2006 and 2009-2010 (see Figs. 5 and 9). During the summer months of 2005-2006, sea ice receded for a longer period in comparison with the other studied years, and this was associated with the highest Chl- $a$ levels in the time series. On the other hand, the summer months of 2009-2010 presented a greater extension of sea ice coverage in February 2010 and lower Chl- $a$ level in the study area. Sea ice extension combined with the timing of the sea ice retreat and time of exposure to sea ice free areas appeared to be important factors controlling phytoplankton establishment in the summer months of 2005-2006 (higher SSC) and 2009-2010 (lower SSC). Considering this information, we suggest that the sea ice retreat exerts an indirect influence on triggering phytoplankton growth by generating sea ice free areas that are essential to phytoplankton blooms. However, the sea ice retreat is not the main factor in modulating phytoplankton dynamics in the BS.

Concerning the phytoplankton community succession in coastal sites around the AP, literature shows that diatoms and/or $P$. antarctica predominately develop in early summer when the sea ice retreat is under way. Later, flagellates such as cryptophytes replace these diatoms, with the final successional stage often displaying small diatoms and unidentified phytoflagellates (Ducklow et al., 2007; Garibotti et al., 2005; Moline and Prézelin, 1996). Our sampling procedures were conducted during mid to late summer (late January-March), and the phytoplankton community varied among the years. Cryptophytes were predominant in late January 2003 and 2004 (see Table 1), except for a few diatom-dominated stations in 2003. Other flagellates were observed in 2008 and 2009 and, as in 2003, diatoms were also more important at stations under TBW influence. The difference in the phytoplankton community observed between the cruises of 2003 and 2004, and 2008 and 2009 could be associated with the differing periods of those campaigns. Cryptophytes and diatoms, mainly C. pennatum, were predominately identified in the January of 2003 and 2004, when sea ice melting was still under way. On the other hand, microplanktonic diatoms and other flagellates characterized a late summer (February-March) phytoplankton community, when the sea ice melting had stopped. Given the scenarios and phytoplankton composition observed in the present study, it could be suggested that the major drivers modulating phytoplankton dynamics along pelagic waters within the BS are dynamics of the TBW and TWW. This has an effect on the position of PF and BF, since the presence of the TBW favors phytoplankton development due to its water 
column structure, characterized by relatively shallow ( $\sim 5 \mathrm{~m}$ ) and well stratified (generally $>2000 \times 10^{-8} \mathrm{rad}^{2} \mathrm{~m}^{-1}$ ) UML, as previously pointed out by Hewes et al. (2009).

Concerning long-term Chl- $a$ fluctuations in the Southern Ocean, modes of climate variability have to be considered as possible influencing factors. For instance, the Southern Annular Mode (SAM) is a dominant climate variability mode over the Southern Hemisphere, varying from intra-seasonal to interannual scales, due to alternations in the atmospheric masses between medium and high latitudes (Gong and Wang, 1999). Positive SAM phases influence the Antarctica climate, intensifying cooling in the region (Gillet et al., 2006). Lovenduski and Gruber (2005) observed Chl- $a$ anomalies (SeaWiFS - 1997-2004) south of the Antarctic Polar Front to be positively correlated with SAM. It was also suggested that positive SAM phases are associated with enhanced westerly winds over the Antarctic Zone, resulting in upwelling movement and increasing iron supply. In the present study, due to both a relatively small sampling area and short time scale, which was less than two complete SAM cycles, a weak $\left(r_{x y}=0.14\right)$ although significant $(\mathrm{p}<0.05)$ relationship was found between SAM and satellite Chl- $a$ time series (data not shown). In addition, El Niño-Southern Oscillation (ENSO) can also influence phytoplankton composition, by impacting on the amount of sea ice, which triggers phytoplankton species variability (Stammerjohn et al., 2008; Yuan, 2004). For instance, ENSO-influenced factors have been suggested to favor cryptophytes as major contributors to the total chlorophyll- $a$ biomass in the summer of 2010 at some sites in the BS (Mendes et al., 2013). During El Niño events, a decrease in northwestern winds results in a/the northward displacement of the Antarctic Circumpolar Current Front and intensification of the Weddell Gyre, allowing Weddell Sea water to flow into the eastern sector of the BS (Loeb et al., 2010). Under those conditions, mixing between oceanic and coastal waters is reduced and Chl- $a$ tends to be low in the BS. In the present work, we suggest that, particularly in cryptophyte-dominated sampling periods (2003 and 2004), those would have been environmental scenarios, with a greater influence of the TWW in the BS. Although no significant influence of ENSO/El Niño events was observed along our relatively short study period, long-term climate variability implications on phytoplankton production is still speculative. Thus, we can suggest that during El Niño events, phytoplankton development in the BS would generally decrease due to a greater outflow of waters advected from the Weddell Sea, and the opposite would be expected during La Niña events.

\subsection{Trophic implications}

Apart from physical and chemical factors controlling the development and distribution of phytoplankton communities, the role of mesozooplankton grazing (e.g., krill and salps) has to be considered. The BS is an important spawning and nursery ground of Antarctic krill (Euphausia superba) and a relevant source of these organisms to other regions of the Southern Ocean (Loeb et al., 1997, 2010). However, the spatial distribution of krill can occasionally overlap with the occurrence of salps in the area, particularly under low Chl- $a$ conditions, caused by an intensification of Weddell Sea water flow into the eastern BS (Loeb et al., 2010).

Concerning grazer-prey associations, the Antarctic krill feeds more efficiently on diatoms than on cryptophytes, while salps are less selective and prey upon a wide spectrum of phytoplankton groups and size classes (Haberman et al., 2003). Therefore, a shift from a diatom- to a cryptophyte-dominated community can significantly affect food-web trophic interactions (Haberman et al., 2003). In this work, a predominance of cryptophytes/flagellates was observed in the 2003, 2004 and 2008 summers, in contrast to the 2009 summer, when diatoms were more abundant. It is possible that in those years of relatively low biomass (2003, 2004 and 2008), phytoplankton assemblages would be suitable for salp development at the expense of the survival and maintenance of krill populations. In 2010, an enormous concentration of salp swarms (visual detection) was observed in the BS, in association with a massive predominance of cryptophytes, estimated from pigment analyses (Mendes et al., 2013). This highlights the tight coupling between phytoplankton assemblages and grazer groups in the Southern Ocean. It has been suggested that shifts in major phytoplankton consumers (salps instead of krill) are most likely caused by recent increases in temperature around the AP, driving changes in phytoplankton assemblages (Moline et al., 2004; Montes-Hugo et al., 2009). Since higher trophic level organisms, such as penguins and seals, preferentially consume krill rather than salps (Loeb et al., 1997), shifts in phytoplankton community composition can generate serious consequences to upper Antarctic trophic levels.

\section{Conclusions}

The Bransfield Strait, considered a Seasonal Ice Zone (SIZ), presented distinct spatial distribution patterns in the phytoplankton community and oceanographic features, in close association with the two main surface waters within the area: the TBW and TWW. Stations under TBW influence, primarily near to the SSI, showed higher Chl- $a$ and a predominance of diatoms, under conditions of shallow UMLD and relatively strong pycnocline. Stations under TWW influence were dominated by "nanoplankton" (cryptophytes or unidentified flagellates) associated with low Chl- $a$ and low stratification levels/low stability values. As phytoplankton biomass and composition were strictly related to the water column conditions of the TBW and TWW, the dynamics of both transitional waters in the BS most likely modulated the spatial variability of the phytoplankton community. Interannual fluctuations were observed in the composition of the predominant phytoplankton groups over the area, varying primarily between diatoms and small flagellates/cryptophytes. The establishment of free ice regions and consequent water column stratification influenced those temporal fluctuations. The low Chl- $a$ associated with a predominance of cryptophytes could be interpreted as a later stage of phytoplankton succession, whereas the high Chl- $a$ coupled with a predominance of diatoms could be related to the establishment of shallow and strong pycnocline. Thus, the dynamics of the TBW and TWW regarding their water column structures were shown to be major driving forces that influence spatial and temporal variability of phytoplankton distribution in the Bransfield Strait. The present work highlighted the need for long-term study programs in the under-sampled BS to resolve interannual fluctuations in phytoplankton composition and biomass, and to better understand the connections between different controlling factors on phytoplankton dynamics. Furthermore, greater sampling efforts are required to gather in situ data in order to provide background information for models about the impacts of climate change on phytoplankton primary production and species composition around the Antarctic Peninsula and, hence, their ecological implications.

\section{Acknowledgments}

This study was conducted within the activities of the GOAL (Grupo de Oceanografia de Altas Latitudes) and SOS-CLIMATE (Southern Ocean Studies for Understanding Climate Changes Issues) projects. These are multidisciplinary programs carried out by the GOAL group activities in the scope of the Brazilian Antarctic Program. The program is coordinated by SECIRM. Financial support was provided by CNPq (National Council for Research and Development) and MMA (Ministry of the Environment). The authors thank the crew of the Brazilian Navy RV "Ary Rongel" and several investigators participating in the cruises for their valuable help during the collection of samples. We are grateful to Ricardo C. Pollery for performing the nutrient analysis, Fernanda R.W. de Oliveira for phytoplankton counting and identification of GOAL samples, and Eduardo M. de Souza for running Chl- $a$ analysis for the 2003 and 2004 cruises. R. Gonçalves-Araujo was funded by an MSc 
grant from CNPq. A PhD fellowship from CAPES (Brazil) was granted to M.S. de Souza. V.M. Tavano and C.A. Garcia are granted with science fellowships from CNPq.

\section{References}

Alderkamp, A.-C., Mills, M.M., van Dijken, G.L., Laan, P., Thuróczy, C.-E., Gerringa, L.J.A., de Baar, H.J.W., Payne, C.D., Visser, R.J.W., Buma, A.G.J., Arrigo, K.R., 2012. Iron from melting glaciers fuels phytoplankton blooms in the Amundsen Sea (Southern Ocean): phytoplankton characteristics and productivity. Deep-Sea Res. II 71-76, 32-48.

Aminot, A., Chaussepied, J., 1983. Manuel dês Analyses Chimiques en Milieu Marin. C.N.E. X.O, Brest.

Amos, A.F., 2001. A decade of oceanographic variability in summertime near Elephant Island, Antartica. J. Geophys. Res. 106, 22401-22423.

Arrigo, K.R., Worthen, D., Schnell, A., Lizotte, M.P., 1998. Primary production in Southern Ocean waters. J. Geophys. Res. 103, 15587-15600.

Arrigo, K.R., Robinson, D.H., Worthen, D.L., Dunbar, R.B., DiTullio, G.R., Van Woert, M., Lizotte, M.P., 1999. Phytoplankton community structure and the drawdown of nutrients and $\mathrm{CO}_{2}$ in the Southern Ocean. Science 283, 365-367.

Arrigo, K.R., Mills, M.M., Kropuenske, L.R., van Dijken, G.L., Alderkamp, A.-C., Robinson, D.H., 2010. Photophysiology in two major southern Ocean phytoplankton taxa: photosynthesis and growth of Phaeocystis antarctica and Fragilariopsis cylindricus under different irradiance levels. Integr. Comp. Biol. 50 (6), 950-966.

Balech, E., 1988. Los dinoflagelados del Atlantico Sudocciental. Publ. Espec. Inst. Esp. Oceangr 1, pp. 1-310, (Madrid).

Bathmann, U.V., Scharek, R., Klaas, C., Dubischar, C.D., Smetacek, V., 1997. Spring development of phytoplankton biomass and composition in major water masses of the Atlantic sector of the Southern Ocean. Deep-Sea Res. II 44, 51-67.

Blain, S., Tréguer, P., Belviso, S., Bucciarelli, E., Denis, M., Desabre, S., Fiala, M., Jezequel, V. M., Le Fevre, J., Mayzaud, P., Marty, J.C., Razouls, S., 2001. A biogeochemical study of the island mass effect in the context of the iron hypothesis: Kerguelen Islands Southern Ocean. Deep-Sea Res. I 48, 163-187.

Boyd, P.W., Watson, A.J., Law, C.S., Abraham, E.R., Trull, T., Murdoch, R., Bakker, D.C.E., Bowie, A.R., Buesseler, K.O., Chang, H., Charette, M., Croot, P., Downing, K., Frew, R., Gall, M., Hadfield, M., Hall, J., Harvey, M., Jameson, G., LaRoche, J., Liddicoat, L., Ling, R., Maldonado, M.T., McKay, R.M., Nodder, S., Pickmere, S., Pridmore, R., Rintoul, S., Safi, K., Sutton, P., Strzepek, R., Tanneberger, K., Turner, S., Waite, A., Zeldis, J., 2000. A mesoescale phytoplankton bloom in the polar Southern Ocean stimulated by iron fertilization. Nature 407, 695-702.

Castro, C.G., Ríos, A.F., Doval, M.D., Pérez, F.F., 2002. Nutrient utilisation and chlorophyll distribution in the Atlantic sector of the Southern Ocean during Austral Summer 1995-96. Deep-Sea Res. II 49, 623-641.

Chatfield, C., 1984. The Analysis of Time Series. Chapman and Hall, New York.

Chelton, D.B., deSzoeke, R.A., Schlax, M.G., Naggar, K., Siwertz, N., 1998. Geographical variability of the first baroclinic Ross - by radius of deformation. J. Phys. Oceanogr. 28, 433-460

Comiso, J.C., McClain, C.R., Sullivan, C.W., Ryan, J.P., Leonard, C.L., 1993. Coastal zone color scanner pigment concentrations in the southern-ocean and relationships to geophysical surface-features. J. Geophys. Res. 98, 2419-2451.

Dodge, J.D., 1982. Marine Dinoflagellates of the British Isles. Her Majesty's Stationary Office, London.

Ducklow, H.W., Baker, K., Martinson, D.G., Quetin, L.B., Ross, R.M., Smith, R.C., Stammerjohn, S.E., Vernet, M., Fraser, W., 2007. Marine pelagic ecosystems: the West Antarctic Peninsula. Phil. Trans. R. Soc. B 362, 67-94. http://dx.doi.org/10. 1098/rstb.2006.1955.

Feng, Y., Hare, C.E., Rose, J.M., Handy, S.M., DiTullio, G.R., Lee, P.A., Smith Jr., W.O., Peloquin, J., Tozzi, S., Sun, J., Zhang, Y., Dunbar, R.B., Long, M.C., Sohst, B., Hutchins, D.A., 2010. Interactive effects of iron, irradiance and $\mathrm{CO}_{2}$ on Ross Sea phytoplankton. Deep-Sea Res. I 57, 368-383.

García, M.A., Castro, C.G., Ríos, A.F., Doval, M.D., Rosón, G., Domis, D., López, O., 2002. Water masses and distribution of physico-chemical properties in the Western Bransfield Strait and Gerlache Strait during Austral summer 1995/96. Deep-Sea Res. I 49, 585-602.

García-Muñoz, C., Lubián, L.M., García, C.M., Marrero-Diaz, Á., Sangrà, P., Vernet, M., 2013. A mesoscale study oh phytoplankton assemblages around the South Shetland Islands (Antarctica). Pol. Biol. 36, 1107-1123.

Garibotti, I.A., Vernet, M., Kozlowski, W.A., Ferrario, M.E., 2003. Composition and biomass of phytoplankton assemblages in coastal Antarctic waters: a comparison of chemotaxonomic and microscopic analyses. Mar. Ecol. Prog. Ser. 247, 27-42. http://dx.doi.org/10.3354/meps247027.

Garibotti, I.A., Vernet, M., Ferrario, M.E., 2005. Annually recurrent phytoplanktonic assemblages during summer in the seasonal ice zone west of the Antarctic Peninsula (Southern Ocean). Deep-Sea Res. I 52, 1823-1841. http://dx.doi.org/10.1016/j.dsr. 2005.05.003.

Gillet, N.P., Kell, T.D., Jones, P.D., 2006. Regional climate impacts of the Southern Annular Mode. Geophys. Res. Lett. 33, L23704. http://dx.doi.org/10.1029/2006GL027721.

Gong, D., Wang, S., 1999. Definition of Antarctic oscillation index. Geophys. Res. Lett. 24 (4), 459-462.

Grasshoff, K., Ehrhardt, M., Kremling, K., 1983. Methods of seawater analysis. Vol. Verlag Chemie, Weinheim

Haberman, K.L., Ross, R.M., Quetin, L.B., 2003. Diet of the Antarctic krill (Euphausia superba Dana): II. Selective grazing in mixed phytoplankton assemblages. J. Exp. Mar. Biol. Ecol. 283, 97-113. http://dx.doi.org/10.1016/S0022-0981(02)00467-7.
Hasle, G.R., Syvertsen, E.E., 1996. Marine diatoms. In: Tomas, C.R. (Ed.), Identifying Marine Diatoms and Dinoflagellates. Academic Press Inc., London, pp. 5-385.

Hewes, C.D., Reiss, C.S., Kahru, M., Mitchell, G.B., Holm-Hansen, O., 2008. Control of phytoplankton biomass by dilution and mixed layer depth in the western Weddell-Scotia Confluence. Mar. Ecol. Prog. Ser. 366, 15-29.

Hewes, C.D., Reiss, C.S., Holm-Hansen, O., 2009. A quantitative analysis if sources for summertime phytoplankton variability over 18 years in the South Shetland Islands (Antarctica) region. Deep-Sea Res. I 56, 1230-1241.

Holm-Hansen, O., Hewes, C.D., 2004. Deep chlorophyll-a maxima (DCMs) in Antarctic waters: I. Relationships between DCMs and the physical, chemical, and optical conditions in the upper water column. Pol. Biol. 27, 699-710.

Holm-Hansen, O., Kahru, M., Hewes, C.D., Kawaguchi, S., Kameda, T., Sushin, V.A Krasovski, I., Priddle, J., Korb, R., Hewitt, R.P., Mitchell, B.G., 2004. Temporal and spatial distribution of chlorophyll-a in surface waters of the Scotia Sea as determined by both shipboard measurements and satellite data. Deep-Sea Res. II 51, 1323-1331.

Holm-Hansen, O., Hewes, C.D., Villafañe, V.E., Helbling, E.W., Silva, N., Amos, T., 1997 Distribution of phytoplankton and nutrients in relation to different water masses in the area around Elephant Island, Antarctica. Pol. Biol. 18, 145-153.

Hoppema, M., de Baar, H.J.W., Fahrbach, E., Hellmer, H.H., Klein, B., 2003. Substantial advective iron loss diminishes phytoplankton production in the Antartctic zones. Glob. Biogeochem. Cycles 17, 1025.01-1025.09.

Jacques, G., Panouse, M., 1991. Biomass and composition of size fractionated phytoplankton in the Weddell-Scotia confluence area. Pol. Biol. 11, 315-328.

Jiang, M., Charette, M.A., Measures, C.I., Zhu, Y., Zhou, M., 2013. Seasonal cycle of circulation in the Antarctic Peninsula and the off-shelf transport of shelf waters into southern Drake Passage and Scotia Sea. Deep-Sea Res. II 90, 15-30.

Koroleff, F., 1969. Direct determination of ammonia in natural waters as indophenol blue. ICES, Hydr. Comm C. M. C: 9.

Kropuenske, L.R., Mills, M.M., van Dijken, G.L., Alderkamp, A.-C., Berg, G.M., Robinson, D.H., Welschmeyer, N.A., Arrigo, K.R., 2010. Strategies and rates of photoacclimatation in two major southern Ocean phytoplankton taxa: Phaeocystis antarctica (Haptophyta) and Fragilariopsis cylindricus (Bacillariophyceae). J. Phycol. 46, 1138-1151.

Loeb, V., Siegel, V., Holm-Hansen, O., Hewitt, R., Fraser, W., Trivelpiece, W., Trivelpiece, S. 1997. Effects of sea-ice extent and krill or salp dominance on the Antarctic food web. Nature 387, 897-900.

Loeb, V., Hofmann, E.E., Klinck, J.M., Holm-Hansen, O., 2010. Hydrographic control of the marine ecosystem in the South Shetland-Elephant Island and Bransfield Strait region. Deep-Sea Res. II 57, 519-542.

López, O., García, M.A., Gomis, D., Rojas, P., Sospedra, J., Sánchez-Arcilla, A., 1999. Hydrographic and hydrodynamic characteristics of the eastern basin of the Bransfield Strait (Antarctica). Deep-Sea Res. I 46, 1755-1778.

Lovenduski, N.S., Gruber, N., 2005. Impact of the southern annular mode on southern ocean circulation and biology. Geophys. Res. Lett. 32, L11603. http://dx.doi.org/10. 1029/2005GL022727.

Marrari, M., Daly, K.L., Hu, C., 2008. Spatial and temporal variability of SeaWiFS chlorophyl a distributions west of Antarctic Peninsula: implications for krill production. Deep-Sea Res. II 55, 377-392.

Martin, J.H., Fitzwater, S.E., Gordon, R.M., 1990a. Iron deficiency limits phytoplankton growth in Antarctic waters. Glob. Biogeochem. Cycles 4, 5-12.

Martin, J.H., Gordon, R.M., Fitzwater, S.E., 1990b. Iron in Antarctic waters. Nature 345, $156-158$.

McGarigal, K., Cushman, S.A., Stafford, S., 2000. Multivariate Statistics for Wildlife and Ecology Research. Springer Verlag, New York, New York, USA.

Menden-Deuer, S., Lessard, E.J., Satterberg, J., 2001. Effect of preservation on dinoflagellate and diatom cell volume and consequences for carbon biomass predictions. Mar. Ecol. Prog. Ser. 222, 41-50.

Mendes, C.R.B., Tavano, V.M., Leal, M.C., de Souza, M.S., Brotas, V., Garcia, C.A.E., 2013. Shifts in the dominance between diatoms and cryptophytes during three late summers in the Bransfield Strait (Antarctic Peninsula). Polar Biol. http://dx.doi.org/ 10.1007/s00300-012-1282-4

Mills, M.M., Kropuenske, L.R., van Dijken, G.L., Alderkamp, A.-C., Berg, G.M., Robinson, D.H Welschmeyer, N.A., Arrigo, K.R., 2010. Photophysiology in two southern Ocean phytoplankton taxa: photosynthesis oh Phaeocystis antarctica (Prymnesiophyceae) and Fragilariopsis cylindricus (Bacillariophyceae) under simulated mixed-layer irradiance. J. Phycol. 46, 1114-1127.

Mitchell, B.G., Holm-Hansen, O., 1991. Observations and modeling of the Antarctic phytoplankton crop in relation to mixing depth. Deep-Sea Res. 38, 981-1007.

Moline, M.A., Prézelin, B.B., 1996. Palmer LTER 1991-1994: long term monitoring and analyses of physical factors regulating variability in coastal Antarctic phytoplankton biomass, in situ productivity and taxonomic composition over subseasonal, seasonal and interannual time scales. Mar. Ecol. Prog. Ser. 145, 143-160. http://dx.doi.org/10. 3354/meps145143.

Moline, M.A., Claustre, H., Frazer, T.K., Schofield, O., Vernet, M., 2004. Alteration of the food web along the Antarctic Peninsula in response to a regional warming trend. Glob. Chang. Biol. 10, 1973-1980. http://dx.doi.org/10.1111/j.1365-2486.2004.00825.x.

Montes-Hugo, M.A., Doney, S.C., Ducklow, H.W., Fraser, W., Martinson, D., Stammerjohn, S.E., Schofield, O., 2009. Recent changes in phytoplankton communities associated with rapid regional climate change along the western Antarctic Peninsula. Science 323, 1470-1473. http://dx.doi.org/10.1126/science.1164533.

Mura, M.P., Satta, M.P., Agustí, S., 1995. Water-mass influences on Summer Antarctic phytoplankton biomass and community structure. Polar. Biol. 15, 15-20.

Nelson, D.M., Smith Jr., W.O., 1991. Sverdrup revisited: critical depths, maximum chlorophyll levels, and the control of Southern Ocean productivity by the irradiancemixing regime. Limnol. Oceanogr. 36, 1650-1651.

Neveux, J., Lantoine, F., 1993. Spectrofluorometric assay of chlorophylls and pheopigments using the least squares approximation techique. Deep-Sea Res. I 40, 1747-1765. 
Prézelin, B.B., Hofmann, E.E., Mengelt, C., Klinck, J.M., 2000. The linkage between Upper Circumpolar Deep Water (UCDW) and phytoplankton assemblages on the west Antarctic Peninsula continental shelf. J. Mar. Res. 58, 165-202. http://dx.doi.org/10. 1357/002224000321511133.

Prézelin, B.B., Hofmann, E.E., Moline, M., Klinck, J.M., 2004. Physical forcing of phytoplankton community structure and primary production in continental shelf waters of the Western Antarctic Peninsula. J. Mar. Res. 62, 419-460.

Rodriguez, F., Varela, M., Zapata, M., 2002. Phytoplankton assemblages in the Gerlache and Bransfield Straits (Antarctic Peninsula) determined by light microscopy and CHEMATX analysis of HPLC pigment data. Deep-Sea Res. II 49, 723-747.

Ryabov, A.B., Rudolf, L., Blasius, B., 2010. Vertical distribution and composition of phytoplankton under the influence of an upper mixed layer. J. Theor. Biol. 263, 120-133.

Sangrà, P., Gordo, C., Hernández-Arencibia, M., Marrero-Díaz, A., Rodríguez-Santana, A., Stegner, A., Martínez-Marrero, A., Pelegrí, J.L., Pichon, T., 2011. The Bransfield current system. Deep-Sea Res. I http://dx.doi.org/10.1016/j.dsr.2011.01.011.

Sangrà, P., García-Muñoz, C., García, C.M., Marrero-Díaz, Á., Sobrino, C., Mouriño-Carballido, B. Aguiar-González, B., Henríquez-Pastene, C., Rodríguez-Santana, Á., Lubián, L.M. Hernández-Arencibia, M., Hernández-León, S., Vázquez, El, Estrada-Allis, S.N., 2014. Coupling between upper ocean layer variability and size-fractionated phytoplankton in a non-nutrient-limited environment. Mar. Ecol. Prog. Ser. 499, 35-46.

Sarmiento, J.L., Gruber, N., Brzezinski, M.A., Dunne, J.P., 2004. High-latitude controls of thermocline nutrients and low latitude biological productivity. Nature 427, 56-60.

Schloss, I.R., Abele, D., Moreau, S., Demers, S., Bers, A.V., González, O., Ferreyra, G.A., 2012 Response of phytoplankton dynamics to 19-year (1991-2009) climate trends in Potter Cove (Antarctica). J. Mar. Syst. 92, 53-66.

Scott, F.J., Marchant, H.J., 2005. Antarctic Marine Protists. Australian Biological Resources Study. Canberra and Australian Antarctic Division, Hobart, p. 563.

Selph, K.E., Apprill, A., Measures, C.I., Hatta, Hiscock, W.T., Brown, M.T., 2013. Phytoplankton distributions in the Shackleton Fracture Zone/Elephant Island region of the Drake Passage in February-March 2004. Deep-Sea Res. II 90, 55-67.

Spreen, G., Kaleschke, L., Heygster, G., 2008. Sea ice remote sensing using AMSR-E 89 GHz channels. J. Geophys. Res. http://dx.doi.org/10.1029/2005JC003384.

Stammerjohn, S.E., Drinkwater, M.R., Smith, R.C., Liu, X., 2003. Ice-atmosphere interactions during sea-ice advance and retreat in the western Antarctic Peninsula region. J. Geophys. Res. 108, 3329-3344.
Stammerjohn, S.E., Martinson, D.G., Smith, R.C., Yuan, X., Rind, D., 2008. Trends in Antarctic annual sea ice retreat and advance and their relation to El Niño Southern Oscillation and Southern Annular Mode variability. J. Geophys. Res. 113, C03S90. http://dx.doi.org/10.1029/2007JC004269.

Steig, E.J., Schneider, D.P., Rutherford, S.D. Mann, M.E., Comiso, J.C., Shindell, D.T., 2009. Warming of the Antarctic ice-sheet surface since the 1957 International Geophysical Year. Nature 457, 459-463. http://dx.doi.org/10.1038/nature07669.

Strickland, J.D.H., Parsons, T.R., 1972. A practical handbook of seawater analysis. Bull. Fish Res. Bd. Can. 167, 310.

ter Braak, C.J.F., 1994. Canonical community ordination. Part I. Basic theory and linear methods. Ecoscience 1, 127-140.

ter Braak, C.J.F., Prentice, I.C., 1988. A theory of gradient analysis. Adv. Ecol. Res. 18, 271-317.

Tréguer, P., Jacques, G., 1992. Dynamics of nutrients and phytoplankton, and fluxes of carbon, nitrogen and silicon in the Antarctic Ocean. Polar. Biol. 12, 149-162.

Turner J. Colwell, S.R., Marshall, G.J. Lachlan-Cope, T.A., Carleton, A.M., Jones, P.D., Lagun, V., Reid, P.A., Iagovkina, I., 2005. Antarctic climate change during the last 50 years. Int. J. Climatol. 25, 279-294. http://dx.doi.org/10.1002/joc.1130.

Utermöhl, H., 1958. Zur Vervollkommnung der quantitativen Phytoplankton-Methodik. Mitt. Int. Ver. Limnol. 9, 1-38.

Varela, M., Fernandez, E., Serret, P., 2002. Size-fractionated phytoplankton biomass and primary production in the Gerlache and south Bransfield Straits (Antarctic Peninsula) in Austral summer 1995-1996. Deep-Sea Res. II 49, 749-768.

Welschmeyer, N.A., 1994. Fluorometric analysis of chlorophyll-a in the presence of chlorophyll-b and pheopigments. Limnol. Oceanogr. 39, 1985-1992.

Wright, S.W., Ishikawa, A., Marchant, H.J., Davidson, A.T., van der Enden, R.L., Nash, G.V., 2009. Composition and significance of picophytoplankton in Antarctic water. Polar. Biol. 32, 797-808.

Yuan, X., 2004. ENSO-related impacts on Antarctic sea ice: a synthesis of phenomenon and mechanisms. Antarct Sci. 16, 415-425. http://dx doi.org/10.1017/S0954102004002238.

Zhou, M., Niiler, P.P., Hu, J.-H., 2002. Surface currents in the Bransfield and Gerlache Straits, Antarctica. Deep-Sea Res. I 49, 267-280.

Zhou, M., Niiler, P.P., Zhu, Y., Dorland, R.D., 2006. The western boundary current in the Bransfield Strait, Antarctica. Deep-Sea Res. I 53, 1244-1252. 